\title{
The role of expectations on consumer interpretation of new information
}

\author{
Lina Tan \\ Nanuka Solutions, Canberra, Australia \\ John Heath Roberts \\ School of Marketing, University of New South Wales, \\ Kensington, Australia, and \\ Pamela Danvers Morrison \\ Department of Marketing, University of Technology Sydney, Ultimo, Australia
}

\begin{abstract}
Purpose - The purpose of this paper is to investigate the role of consumers' expectations and their antecedents on beliefs, attitude and behavioral intentions when they respond to new corporate social responsibility (CSR) information about a service firm.

Design/methodology/approach - Empirically, the authors measure prior beliefs, and then calibrate how those beliefs change in response to a piece of news. The authors develop a conceptual model articulating the nature and antecedents of three types of expectations: would, could and should. The authors use structural equation modeling to test how these expectations influence the consumer evaluation process.

Findings - The results show that the effect of could expectations on the evaluation process is felt via their influence on would expectations; that is, would expectations fully mediate the relationship between could expectations and attitude toward news. Similarly, attitude toward news fully mediates the relationship between would and should expectations and updated beliefs about the firm.

Research limitations/implications - In the selected service industry, the findings show that expectations are mediated by the new information that consumers receive when they are updating their prior beliefs. The authors demonstrate the ability to understand the antecedents of expectations, which provides a vehicle by which the organization can influence the consumer evaluation process.

Practical implications - In practice, managers can identify the antecedents of consumer expectations and thus influence the reference points against which those consumers will evaluate news about their product.

Social implications - CSR has important implications for multiple stakeholders and the authors calibrate the determinants of how news about the organization's performance on it may affect consumer decision processes.

Originality/value - The paper introduces "could" expectations into the services literature, examines the antecedents of the different types of expectations, and studies how their effect is felt through the evaluation process. Keywords Corporate social responsibility, Services, Expectations, Behavioural intentions, Updating Paper type Research paper

\section{Introduction}

This paper examines the role of expectations and their antecedents in shaping consumer evaluations and behavioral intent toward a service organization. It does so by studying the effect of a piece of news about the firm, specifically information about its corporate social responsibility (CSR) performance. Firms are facing increasing pressures to both maintain profitability and market share, as well as to be socially responsible (Korschun et al., 2014; Du et al., 2010). Surveys of public expectations consistently show an organization's social responsibility matters (e.g. Epstein-Reeves, 2010; Cone, 2013). Epstein-Reeves (2010) demonstrates that consumers expect companies to achieve their corporate objectives while improving society and the environment in which they operate. Imagine the CEO of a
\end{abstract}

This paper forms part of a Special section ANZMAC 2015.
Role of expectations on consumer interpretation

Received 4 April 2016 Revised 29 August 2016 8 December 2016 Accepted 28 January 2017 
JSTP

27,3

services firm. She knows that expectations shape the way in which consumers evaluate her service, but she does not know the total nature of those expectations, whether expectations operate by the consumer evaluating news about the firm differently or by directly operating on beliefs and attitudes, and what factors lead to those expectations. We aim to address those issues.

In assessing how consumers integrate new information, we consider their expectations. Expectations represent an influential force in shaping judgments and subsequent behavior (Boulding et al., 1993; Korschun et al., 2014; Polo and Sese, 2013). CSR expectations are already being felt by many industries, with consumers now far more likely to demand more socially and environmentally responsible products and fair employee treatment and compensation (Lii and Lee, 2012; McPherson, 2016), and ethically oriented product communications demonstrating beneficial impact on the brand performance of firms (McPherson, 2016; Shaw et al., 2005). A number of studies suggest that media exposure of a corporation's CSR practices has the potential to influence consumer beliefs and reactions toward it (e.g. Manheim and Albritton, 1984; Raghubir et al. 2010). The adverse consequences of media coverage of a range of negative news such as the Enron accounting scandal, the GlaxoSmith Kline off-label marketing fraud and the mishandling hazardous waste by ValuJet have underscored the importance of meeting stakeholders' varied social expectations (Dezenhall and Weber, 2011).

The literature on consumer service encounter evaluations suggests that a judgment of a firm's CSR activities is likely to be evaluated relative to a set of preformed expectations (e.g. Boulding et al., 1993). Recently, understanding consumer expectations has become increasingly important (Klein and Dawar, 2004; Korschun et al., 2014) as evidence mounts that they are linked to the firm's value creation, firm valuation and revenue performance (e.g. Luo and Bhattacharya, 2006; Ioannou and Serafeim, 2015). Although the role of expectations is widely acknowledged as an integral part of CSR evaluation, few studies have calibrated and discussed them in detail (Smith et al., 2010). Another relatively unexplored area of research is the identification of the antecedents of expectations. Within the service quality literature, Zeithaml et al. (1993) acknowledge enduring and transitory service intensifiers, situational factors (such as random excess demand), word of mouth and predictions as influencers of expected and minimum service levels. However, their study does not identify antecedents of consumer expectations, nor their impact on evaluative and behavioral outcomes. Thus, as well as consequences of consumer expectations, there is a need to develop a deeper understanding of expectations' antecedents and the role they play as comparative referents for CSR news evaluation.

In this research, we empirically investigate different types of expectation that exist for consumers evaluating CSR news about an airline and identify the key antecedents that drive consumer expectations of the airline's corporate social performance. In addition, we explore the role that expectations play in influencing airline passenger beliefs about, attitude toward, and intentions regarding the airline. This paper aims to add to the service marketing literature by providing a conceptual model of how different types of expectation constitute an important mechanism with which to understand consumer response to CSR news. In developing and testing the model, we make both theoretical and practical contributions to literature. From a theoretical perspective, our work is the first of which we are aware to distinguish between the antecedents of three expectations standards - would, could and should expectations - and to explore the direct and indirect relationships between them. Results of the current study also contribute to the knowledge of the factors driving airline passenger expectations and consumer attitudes and reactions toward new information. Our study exploits the theoretical complementarities of a number of related literatures including, first, the resource-based view of the firm (RBF) and second, external environmental constraints. It also contributes by proposing a third expectations standard could expectations (where could expectations refer to possible performance, not ideal or 
should performance). We expect empirical findings on could expectations will provide insights into consumers' attributions as to whether good or poor CSR performance is the result of the internal or external constraints that the firm faces or a lack of desire or culture to harness its resources to address the situation. This has implications for marketing managers, who may need to undertake different actions, depending on whether news is perceived to be within the control of the firm or not.

\section{Expectations and their antecedents}

\subsection{Expectations}

Expectations may be defined as beliefs and predictions about the future (Olson and Dover, 1979). They represent an essential psychological mechanism that affects virtually all human behavior. The significance of expectations and their role in evaluating the perceptual outcomes from the customer's perspective have been emphasized by scholars. For example, Bandura's (1977) general social cognitive theory focuses on the formation of expectations, the selection of choice options, and performance. He classifies these expectations into categories of physical outcomes, social outcomes and self-outcomes. In the social psychology literature, attribution theory describes how an individual uses expectations and information to explain events. Attribution theory holds that expectations for specific outcomes ultimately help to shape emotional and behavioral responses (Weiner, 1985). Expectancy-theory posits that intentions to perform behaviors and perceived behavioral control can be used as proxies for expectations (Ajzen, 1991). Ajzen (1991) notes that when studying individuals' behaviors that have a clear moral dimension, it is appropriate to add a measure of moral norm in the expectancy-value model to determine whether it adds to the prediction of intention and behavior. In the present study, we considered should expectations as an additional determinant of beliefs and attitudinal formations.

Within the studies on customer satisfaction, expectations are postulated to have an effect on satisfaction mainly due to their role as a continually adjusted anchor of information in the satisfaction evaluation process (Johnson et al., 1995; Polo and Sese, 2013). This anchor of information is the psychological equivalent of the cognitive process of anchoring and adjustment (Tversky and Kahneman, 1974). The idea of a reference point around which to benchmark evaluations is common in many management disciplines (see, e.g. Herzberg et al. 2011). In marketing, the disconfirmation model (also known as the gap model) refers to judgments that a person makes with respect to his or her satisfaction with a firm's product or service performance in comparison to the person's prior expectations. According to Oliver's (1980) expectancy disconfirmation paradigm, one of the three outcomes will occur when disconfirmation takes place: confirmation, when the actual product/service performance matches expectations; positive disconfirmation, when the actual product/ service performance exceeds expectations; and negative disconfirmation, when the actual product/service performance fails to meet expectations. In particular, the disconfirmation model posits that expectations have a negative influence on disconfirmation; higher expectations are less likely to be met (negative disconfirmation) thus leading to lower satisfaction levels while lower expectations are more likely to be exceeded and are predicted to lead to higher satisfaction levels. In a similar manner, Zeithaml et al. (1993) described service quality as a comparative function between various types of consumer expectations (desired, adequate and predicted) and actual service performance. Of particular interest is the zone of tolerance between the range of customers' desired (should) and minimum acceptable (would) expectations and the actual performance. Performance below the zone is seen as dissatisfying and performance above the zone is seen as delighting. See Yuksel and Rimmington (1998) and James (2009) for a critique of the disconfirmation model. Several studies point out that the discrepancies between perceived performance and expectations increase the likelihood of disconfirmation effects (Ho et al., 2015; Teas, 1993). 
JSTP

27,3

It is possible that when testing the disconfirmation model, the direct path from expectations to satisfaction will not be significant, indicating the need to look for a more complete model of expectations. Of particular relevance to our study is the operationalization of could expectations as they relate to new information about a firm.

The importance of expectations in judging quality specifically in service industries has attracted much attention (Ho et al., 2015; Johnston, 2004; Polo and Sese, 2013; Sachdev and Verma, 2004; Saunders, 2015; Strombeck and Shu, 2014; Zeithaml, 2002). Expectations have also attracted attention in the study of CSR. A growing body of studies on CSR have demonstrated that firms are increasingly aware of the need to address stakeholders' humanitarian, social and environmental concerns beyond immediate financial rewards (Bhattacharya et al., 2009; Carroll and Buchholtz, 2011; Friedman, 1970; Raghubir et al., 2010). Creyer and Ross (1997), Homburg et al. (2013), and Vallaster et al. (2012) all find that expectations have a positive influence on stakeholders' decision making. In addition, several studies have suggested that individuals' perceptions of CSR issues may depend on pre-existing views and the type of news to which they were exposed (Klein and Dawar, 2004; Ioannou and Serafeim, 2015). Specifically, individuals may evaluate a piece of information about the firm relative to a set of expectations, and these expectations may influence how they perceive and react toward the focal firm. With the increasing institutionalization of CSR (Du et al., 2010; Korschun et al., 2014), understanding stakeholders' diverse expectations has become a key variable to a firm's success (Freeman, 1984; Raghubir et al., 2010; Smith et al., 2010). Past research has found that expectations that are relevant to an individual's needs are frequently activated and, therefore, are likely to influence changes in his/her perceptions when presented with a stimulus (Boulding et al., 1993; Korschun et al., 2014). Behavioral responses can be in the form of altered purchase intentions (upwards or downwards), word of mouth, shareholder activism, boycotts and adverse publicity in the media (Bhattacharya et al., 1995; Klein et al., 2004; Smith et al., 2010). In this study, consumer expectations about a firm are decomposed into their beliefs about what the firm would, should and could do in a given situation. Hence, to understand how consumers update their beliefs about, attitudes toward, and intentions with respect to future consumption of the firm's services in the light of new information, we focus on these three expectation benchmarks (would, should and could expectations). We identify likely antecedents of each of these expectations in a CSR context.

\subsection{Would expectations and their antecedents}

Would expectations are the most commonly used benchmark for evaluating future performance (Boulding et al., 1993). Would expectations represent the pre-stimulus beliefs about the firm's expected future performance (Olson and Dover, 1979). In the CSR context, would expectations are described as a consumer's prediction of the likely performance of the firm, based on prior beliefs, commitment and explicit and implicit promises made by it. When a consumer recalls past behavioral experiences with a service provider, he/she is likely to recall evaluative judgments (Mather and Johnson, 2000). This in turn can influence his/her expectations about the firm's future likely performance. Organizational culture underpins a firm's past actions and implicitly makes promises about how the firm will operate in the future (de Vries and Miller, 1986). Consumer perceptions of organizational culture provide a frame of reference for them to predict what a firm would do in a given situation (Trice and Beyer, 1984). Boulding et al. (1993) acknowledge that consumers' would expectations act as a positive reality filter of a firm's future actions.

\subsection{Should expectations and their antecedents}

While would expectations, as a predictive concept, has dominated most of the literature, it fails to account for the innate wants and personal values of individuals (Kahneman and 
Miller, 1986). In contrast, should expectations add a normative aspect to the simple would expectations model (Ajzen, 1991). Normative expectations have been described as "ideal expectations," or "wished for" or "desired" level of performance in meeting consumers' needs and wants (Cadotte et al., 1987; Miller, 1977; Swan and Trawick, 1980; Zeithaml et al., 1993). They describe the customer's preferred level of product performance (Swan and Trawick, 1980) and suggest how a brand should perform (Prakash, 1984). In the CSR context, should expectations are viewed as reflecting the needs or values of consumers (Donaldson and Preston, 1995) - that is, what they feel a firm should do rather than what it would do in the provision of CSR. Should expectations involve a quality that philosophers sometimes term "ought" (Tse and Wilton, 1988). Should expectations may incorporate what a stakeholder has learned, such as personal experience with a competing firm, thus at least partially holding all firms to a common standard (Boulding et al., 1993; Cadotte et al., 1987). While positive service encounters with the firm can increase a consumer's would expectations of a firm's next service level, should expectations are more dependent of external factors such as when consumers experience a higher standard of service quality from a competing firm (Boulding et al., 1993; Ho et al., 2015; Teas, 1993).

Past research has found that should expectations relevant to an individual's needs are activated frequently and are likely to influence the perceptions that consumers have when presented with a stimulus (Becker-Olsen et al., 2006).

\subsection{Could expectations and their antecedents}

Should and would expectations do not directly provide a basis for the stakeholder to estimate a firm's ability to engage in CSR. In this paper, we propose a third standard of expectations - could expectations. The nature of could expectations has not, to our knowledge, been studied in a services nor CSR news context.

The expression "could expectations" has been used in communications theory (Olkkonen and Luoma-aho, 2014), but with a very different meaning. We find it ironic that Olkkonen and Luoma-aho (2014) use the term with respect to an ideal benchmark, rather than a possible one. Indeed, the authors explain their use of the term as follows:

The fourth basis ideal expectation, was an ideal possibility or hope that may not be realistic but is held as an ideal. As these expectations describe what could be, we call them the "could" expectations (Italics added).

In marketing and services terminology, this more closely corresponds to should expectations and so we prefer to reserve the term could expectations to refer to what consumers perceive as possible.

Could expectations are distinct from would expectations in that they address the firm's capability to advance CSR through a combination of internal resource opportunities and environmental barriers, while would expectations predict a firm's actions by the organization's implicit and explicit promises to advance CSR.

We posit that consumers' expect what a firm will do (would expectations) to be the intersection (overlap) of what it is capable of doing (could expectations) with what it is motivated to use that capability for. Drawing on RBF (Wernerfelt, 1984), we argue that a consumer may infer the expected ability of what a firm could do by comparing his/her perception of its strategic internal resources to the external environmental opportunities and barriers it faces. Resources are primary determinants of a firm's ability to perform (Barney, 1986). A consumer's perception of a firm's ability to apply internal resources to leverage its skills will influence his/her perception of the firm's ability to engage in CSR (Kull et al., 2016; Russo and Fouts, 1997). Additionally, since firms are embedded in a system of specific political, social, cultural and legal conditions and rules, external environmental factors (over which they have limited influence) will also influence could 
JSTP

27,3

574

expectations. Miller and Friesen (1983, p. 222) characterize such environmental challenges as "the degree of threat to the firm posed by the multi-facetedness, vigor and intensity of the competition and the downswings and upswings of the firm's principal industry." A person's perception of the internal and external environmental factors will vary according to their personal schemas and the competitive perspective with which they view the marketplace. Because of these phenomena, the RBF lens provides an important platform for a consumer to quantify the strategic value of resources that a firm may have access to, or the barriers it may face to create a competitive advantage (thus driving could expectations).

In summary, we posit that three different sets of expectations influence the manner in which the evaluation process takes place and we identify the likely antecedents of those expectations based on the literatures relevant to each.

\section{Conceptual model and hypothesis development}

To develop a conceptual model of how expectations influence evaluation and behavioral intentions, we draw on Ajzen's (1991) theory of planned behavior and extend Boulding et al.'s (1993) model of service quality. Our model highlights the sources of knowledge on which expectations are based, as well as the outcomes that these expectations have been shown to influence. As advocated by Urban and Karash (1971), we adopt an evolutionary approach to model development. The three stages of our model, illustrated in Figure 1, consist of: a base model of information integration; the incorporation of expectations; and the inclusion of the antecedents of expectations.

\subsection{Stage 1 - establishing the base model}

Our base model is predicated on the assumption that consumers have prior beliefs about the firm at time $t$. Empirical studies have suggested that these beliefs about the firm and its CSR actions will determine their attitude toward it (e.g. Bhattacharya et al., 2009). Attitudes act as a determinant of behavioral intentions. Consistent with Ajzen's (1991) theory of planned behavior, we expect that consumers' evaluation of a firm determines their attitudes toward it, which influences their behavior at time $t$. Next, this standard model of beliefs-attitudebehavior at time $t$ is updated to develop a set of posterior beliefs at time $t+1$ when the consumer is confronted with new information. This approach comes from the dynamic

Figure 1.

The full conceptual model

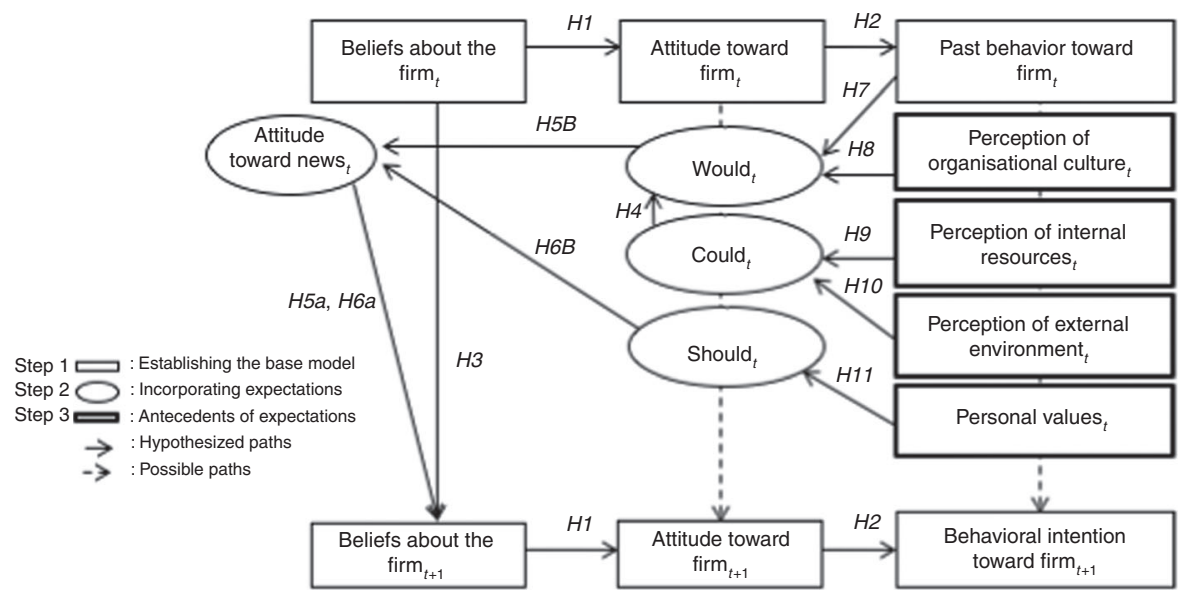


brand choice literature (Roberts and Urban, 1988). It is represented by the top and bottom lines of Figure 1. We posit that:

H1. Attitudes toward a firm $t$ will be positively related to beliefs about the firm .

H2. Behavior toward a firm $t$ will be positively related to attitudes toward the firm . $_{\text {. }}$

Role of
expectations

on consumer interpretation

H3. Beliefs about a firm $t_{t+1}$ will be positively related to beliefs about the firm .

We claim no contribution to this base model, but its pedigree gives us a sound foundation from which to address the role of different types of expectations and their antecedents. Note that we are agnostic as to the information on which prior beliefs are based. It is their updating in which we are interested.

\subsection{Stage 2 - incorporating expectations}

To understand how different expectations affect the base model, we include all three expectations (would, could and should) into the base model. RBF postulates the competitive position of an enterprise depends on the quality of internal resources and the firm's adaptability to the external market environment. Hence, a person's could expectations of a firm provide the basis of how the individual expects it will act (would expectations) (Srivastava et al., 2001). Therefore, we hypothesize:

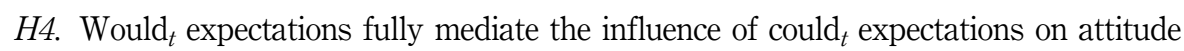
toward news ${ }_{t}$.

Drawing on information processing theory, we argue that upon exposure to a given piece of CSR news, consumers will evaluate it relative to their expectations (would and should) and so expectations will influence how the consumer evaluates the news. Since there is no new information available to the consumer available at time $t+1$ that was not available at time $t$, except for the CSR News, we do not anticipate that expectations will have a direct effect on beliefs, attitudes and intentions in time $t+1$, except that which is felt through the interpretation of the news. Similarly, because the theory of planned behavior (Ajzen, 1991) suggests that intentions form as a result of attitudes and attitudes are based on beliefs, we do not expect direct effects of attitudes and intentions in time $t$ on attitudes and intentions in time $t+1$, respectively. We posit that changes in attitudes and intentions will occur as a result of changes in beliefs (see Figure 1). That is, expectations influence consumers' attitudinal response toward the news and that response will be incorporated in their updated CSR beliefs about, and attitude toward, the firm, illustrated in Figure 1. This leads to the following set of hypotheses:


about a firm fit $_{\text {. }}$

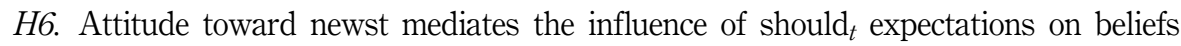
about a firm fir $_{t}$.

\subsection{Stage 3 - proposing the antecedents of expectations}

In the final stage of model development, we propose the antecedents of expectations to facilitate an understanding of how consumers form their would, could and should expectations. Previous studies have found that a person's past behavior influences attention to and the absorption of new knowledge (Tripsas and Gavetti, 2000). Extending this logic to the relationship between a person's past behavior toward the firm and would expectations, we argue that individuals form expectations of what a firm would do based on their past 
JSTP

27,3

behavior (experience) with it. That is, people shift their expectations to be consistent with their past experience with the organization. Specifically, we propose that:

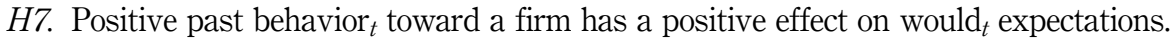

As consumers may not have perfect information about a firm's performance, they often rely on extrinsic cues to develop their expectations about its CSR engagement (Fiske and Nueberg, 1990). One key extrinsic cue is their perception of the firm's organizational culture. Individuals may use their impression of the firm's culture, such as fairness toward people and good corporate citizenship (Brown, 1997), to infer expectations of it. We therefore propose that:

H8. Higher perceptions of a firm's organizational culture have a positive effect on would $_{t}$ expectations.

RBF suggests that both superior resources and a supportive external environment may enable the firm to operate effectively (Barney, 1991). Consumer perceptions of a firm's ability to mobilize resources and the supportiveness of the external environment will enhance their could expectations of a firm's CSR performance (Kull et al., 2016). Hence, we posit that:

H9. Perceptions of a firm's superior internal resources ${ }_{t}$ have a positive effect on could $_{t}$ expectations.

H1O. Perceptions of a supportive external environment ${ }_{t}$ have a positive effect on could $_{t}$ expectations.

In his exploration of the psychology of motivation, Hume (1978) argued that regardless of what beliefs individuals may hold, their moral values drive their normative (should) expectations because they are motivated by a desire for consequences consistent with their values. Given that consumer values also provide the basis of how firms should conduct its activities, it is reasonable to assume that consumer values will influence their should expectations (Boulding et al., 1993; Rokeach, 1968). This leads to our final hypothesis:

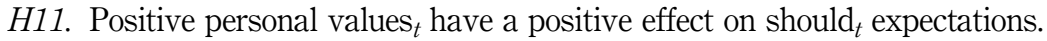

\section{Data and methods}

To calibrate expectations and their antecedents, and to develop appropriate stimulus materials, we employed a mixed method approach: semi-structured interviews, pre-testing and a pilot study, followed by the main study (online survey). Air traveler expectations of the focal corporation, QANTAS Airways, were elicited and tested[1]. QANTAS is a leading airline based in Australia with strong domestic and international networks. An airline provides an ideal context for testing our model in a service industry. Within the commercial aviation industry, air travelers' expectations are important drivers of repeat airline choice. As the competition between airlines intensifies, identifying the service expectations that matter most to airline customers is an important factor in creating a competitive advantage in performance (Danaher et al., 2011; Parasuraman et al., 1994; Sachdev and Verma, 2002). Some of the key attributes to delivering superior airline service quality include reliability in maintaining flight schedules, a good safety record, perceived social responsibility, and helpful employees. Moreover, beliefs gained through their personal experience greatly affect perceptions, attitude and repeat purchase (Goldsmith et al., 1994; McKercher et al., 2003).

\subsection{Qualitative understanding of the consumer evaluation process}

We conducted in-depth semi-structured interviews with seven air travelers to elicit the type of items respondents use to think about the constructs in the model. The interview 
transcripts were analyzed via NVIVO to identify keywords, themes and patterns salient to airline passengers (Richards, 1999). From the results of the interviews, we generated a starting list of appropriate attributes (used for pre-test questionnaire) (see Appendix 1). In all, 25 expert raters (consisting of academics, senior travel intermediaries and travelers) participated in the pre-test. They were asked to assess relevance and face validity of constructs, identify incongruent items and appraise the suitability of the terminology in an airline context (Podsakoff et al., 2003). For the pilot study, respondents were asked to answer a battery of self-stated importance measures to test the items and were then randomly exposed to a news article (positive or negative) involving the focal airline's CSR policy. In all, 250 air travelers participated in the pilot study. We conducted an ANOVA to assess the effectiveness of news manipulations and expectations. We followed the method that Steenkamp and Van Trijp (1991) propose, using exploratory factor analysis and then confirmatory factor analysis (CFA) to validate the constructs (see Table AI). This analysis confirmed that the factor structures were adequate. All constructs had reliability coefficients greater than the suggested level of 0.70 (Hair et al., 1995).

\subsection{Data collection procedure}

To mitigate against potential collinearity and Type II errors, we followed the guidelines by Grewal et al. (2004) in our measure development. We used feedback from interviews and pretests, and existing measures based on constitutive definitions and the relevant literature for measurement construction, following Rossiter's (2002) C-OAR-SE procedure. All research constructs were measured using multiple-item seven-point Likert scales adapted from previous studies. For multiple scales, the order of items was randomized to minimize response-set artifacts (Rossiter, 2002, p. 324). Questions of a similar nature were worded differently in various sections of the questionnaires as a test-retest reliability check. Based on the pilot and pre-test, minor modifications were made to the survey (see Tan, 2013 for details of the procedures and Appendix 4 for specific item measures).

The constructs in our study are: Beliefs about firm at time $t$ and $t+1$ (16 indicators), attitude toward the firm at time $t$ and $t+1$ (four indicators), past behavior toward the firm at time $t$ (and behavioral intention toward the firm at time $t+1$ ) (four indicators), attitude toward news (four indicators), would, should and could expectations (six indicators each), perceptions of organizational culture (eight indicators), perceptions of internal resources (seven indicators), perceptions of external environment (seven indicators) and personal values (six indicators), all at time $t$. The items employed for the 11 constructs were based on the following considerations. First, we included items based on the literature in the commercial aviation market context and from earlier interviews. Second, we adopted scales where available from previous studies with valid and reliable measures of corresponding constructs (see Table I). Finally, we considered items that measure the content of each construct and to determine the extent to which they represent definitions and dimensions. For example, behavior (and behavioral intentions) toward the firm were measured using a four-item question on a seven-point scale from (1) strongly disagree to (7) strongly agree, adapted from Fishbein and Ajzen (1975) and Bhattacharya et al. (1995). Examples include "I [will] choose Qantas as my first choice whenever possible" and "I[will] speak highly of Qantas to other people." Because new scales were developed using items from various measures and adapted from prior interviews, we also tested their validity and reliability to ensure that the new scales were acceptable. Prior to use in the main study, all items were tested and refined in a pilot study with an independent sample. The various constructs were adapted from a number of sources (Table I). In sum, a total of 74 scale items were used to measure the 11 constructs in the model. The Cronbach $\alpha$ for all constructs were greater than 0.70 . 
Beliefs about firm at time $t$ and $t+1$

\section{8}

Table I.

Scales used to represent the constructs
Attitude toward the firm at time $t$ and $t+1$

Past behavior(oral) (intention) toward the firm at time $t / t+1$ Attitude toward news

Would expectations

Should expectations

Could expectations

Perceptions of organizational culture Perceptions of internal resources Perceptions of external environment Personal values at time $t$
8 Service quality items adapted from Parasuraman et al.'s SERVQUAL

4 Reputational items adapted from Danaher et al. (2011)

4 CSR items developed from Carroll's (1979) environmental and social well-being aspects of CSR

4 Attitude scale developed from Ajzen and Fishbein's attitude scale

4 Behavior(oral) (intentions) items adapted from Fishbein and Ajzen (1975) and Bhattacharya et al. (1995)

4 Attitude toward news items adapted from Fishbein and Ajzen's (1975) attitude scale

6 Adapted from Ruf et al. - to evaluate the importance of Kinder,

6 Lydenberg and Domini's (KLD) eight social performance

6 dimensions

8 Organizational culture items adapted from Chatman and Jehn

7 Internal resources items adapted from Grant

7 External environment items adapted from Russo and Fouts (1997)

6 Personal value items adapted from Schwartz's value (benevolence) scale

\subsection{Stimuli}

Based on the results of the pre-test, we calibrated two versions of the "airline's CSR news story," positively and negatively valenced[2]. These two stimuli were pilot-tested with passengers. The stimulus consisted of a news write-up about the focal airline's proposed CSR actions, including information about its CSR policy. As a stimulus manipulation check, respondents were asked to identify the nature of the news. One way ANOVA results indicated a significant difference between groups' attitude toward the news stimuli.

\subsection{Common method variance}

To control for common method variance and consistency bias, we considered the following three recommendations. First, we followed the procedural remedies suggested by Podsakoff et al. (2003) by using the CSR news stimulus as a psychological separation and different response format as methodological separation in our main study. Second, we adopted Lindell and Whitney's (2001) suggestion to include a construct (category complexity) that is uncorrelated to other constructs. The category-complexity construct involves a consumer's perception of the type of news that was used in the study and does not influence their expectations of the firm. Third, we used the Harman single factor test to assess whether a single factor would account for a large part of the variance of the independent and criterion variables based on consumers' self- report (Podsakoff et al., 2003). A single factor model yielded a very poor fit to the data (comparative fit index (CFI): 0.661, Tucker Lewis Index (TLI): 0.614, root mean square error approximation (RMSEA): 0.298), suggesting that common method variance is not a serious threat.

\subsection{Main study}

The main study comprised a population of air travelers provided by an online panel firm. In the recruitment e-mail invitation sent to the online panel, respondents were provided with the general purpose of the study, an explanation of the CSR news story stimulus and were assured of the confidentiality of their responses (see Appendix 3 for the solicitation e-mail). 
(We debriefed respondents about the hypothetical nature of the news at the end of the survey.) Respondents were randomly assigned to one of the two CSR stimuli: positive or negative news (Abbott and Bordens, 1991). A reminder e-mail was sent to respondents ten days after the first e-mail invitation. 781 passengers fully completed the survey representing a 69.3 percent response rate of those who volunteered for the survey. Respondents first indicated their beliefs, attitude and behavior toward the firm. Next, we elicited their would, could and should expectations and they were asked to rate how the focal company is likely to perform on each of the antecedents of those expectations. After reading the news, respondents were again asked to indicate their beliefs, attitude and behavior toward the firm to collect their posteriors.

\subsection{Data analysis}

The conceptual distinction between expectations, their antecedents, and their outcomes, has implications for our analysis. Because of this distinction, we employed a two stage data analysis approach, following the procedures proposed by Bart et al. (2005). We used structural equation modeling (SEM) with Mplus 7.1 to first estimate a measurement and structural model and second assess the mediating effects of attitude toward news and expectations. We adopted the recommendation by Tabachnick et al. (2001) for missing data before estimating the model. We examined residual plots against independent variables to examine the linearity assumption and we evaluated both univariate and multivariate normality indexes to assess normality. Results of those tests suggest that linearity and normality assumptions are satisfied.

\section{Results}

\subsection{Descriptive results}

The 781 respondents consisted of adults over 21 years of age, with a mean age of 46 . The gender split for air travelers was roughly equal: slightly more than half of the sample was female (51 percent). The survey heavily represented infrequent flyers with over three-quarters of the respondents indicating that they had traveled only between one and five trips in the past 12 months. This is consistent with the overall population of airline travelers. There are a number of interesting findings using just exploratory data analysis, looking at the means and standard deviations of our constructs. These numbers are contained in Table AIII.

\subsection{Main study results}

As $\chi^{2}$ is highly sensitive to sample size when used as a measure of model fit, we used CFI, TLI and RMSEA as alternative measures. The data measurement model revealed that the model's fit was acceptable $(\mathrm{CFI}=0.961$, TLI $=0.943$, RMSEA $=0.048)$. The item loadings obtained from the CFA confirmed the unidimensionality of all constructs (items loadings ranged from 0.847 to 0.968 ). The reliabilities of all items in this study were greater than 0.71 , suggesting high item reliability. Average variance extracted (AVE) values ranged from 0.610 to 0.814 (exceeding the suggested minimum threshold of 0.5) indicating high discriminant validity between pairs of constructs. We concluded that convergent validity did not pose a significant threat to our results.

The correlation matrix (Table II), used to test the measurement model, shows that all hypothesized relationships were significant at the 0.01 level. These results provide additional support for the CFA results regarding the construct and discriminant validity of the study variables. These correlations met the conditions of mediation described by Preacher and Hayes (2008) and conveyed useful information about the level of dependence. 
JSTP

580

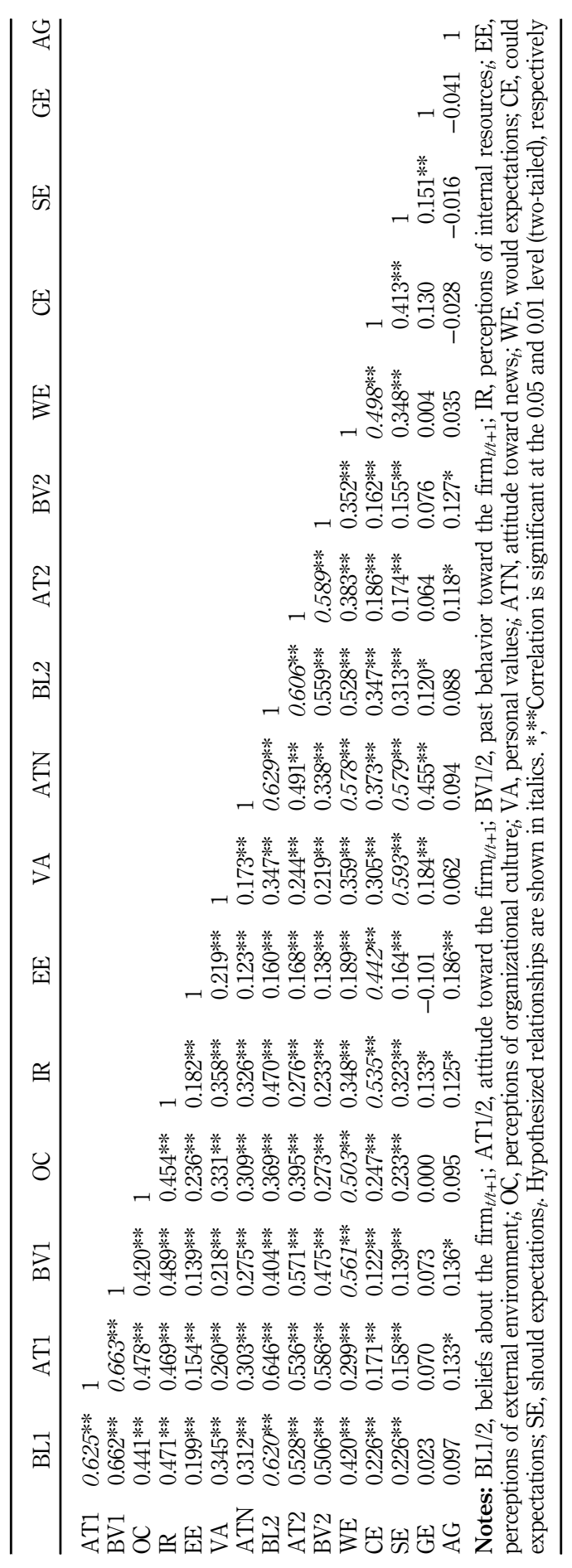

Table II.

Measurement model: correlation matrix of constructs (plus gender and age) 
SEM results (Table III) affirm the effects of beliefs about the firm on attitude toward the firm ( $\left.\beta_{t}=0.699, p<0.01, \beta_{t+1}=0.470, p<0.01\right)$, attitude toward firm on behavior toward the firm $\left(\beta_{t}=0.202, p<0.01, \beta_{t+1}=0.354, p<0.01\right)$, and beliefs about the firm on on beliefs about the firm fit $_{1}(\beta=0.500, p<0.01)$. Contrary to $H 7$, past behavior toward the firm was found to be negatively related to would expectations $(\beta=-0.044, p<0.05)$. Otherwise, all hypothesized relationships held. Perceptions of organization culture were found to have a positive relationship with would expectations $(\beta=0.063, p<0.1)$. Perceptions of internal resources $(\beta=0.699, p<0.01)$ and external environment $(\beta=0.166, p<0.01)$ were found to have a positive effect on could expectations while personal values were found to influence should expectations $(\beta=0.438, p<0.01$ ). Thus, $H 1-H 3$ and $H 8-H 11$ are supported. $H 7$ is not supported. The weak negative relationship between consumers' past experience with the focal firm and their would expectations of its future actions is consistent with a turbulent market in which the past is no longer a good predictor of the future. On October 29, 2011 the CEO of QANTAS announced that the firm was locking employees out of its facilities and ceasing all flights until further notice, leaving many QANTAS passengers stranded[3]. This research, conducted less than six months after this event, may reflect that consumer expectations had still not yet recovered from this unexpected behavior.

\subsection{Mediation results}

Next, we performed tests of mediation using the recommendations by Iacobucci et al. (2007). We assessed statistical significance of the mediation effect with Sobel's $z$-test. We used indices from Mplus 7.1 that estimates the sizes of "indirect" effects and "total" effects, and formed the ratio of indirect-to-total effects (Preacher and Hayes, 2008). Mediation results (Table IV) show

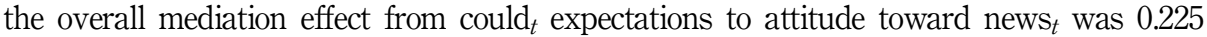

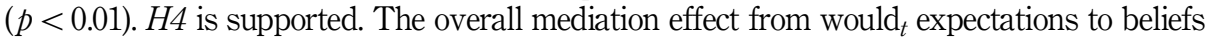
about the firm fit $_{t}$ was $0.104(p<0.01)$ and the overall mediation effect should expectations to $^{2}$ beliefs about the firm $t_{t+1}$ was $0.340(p<0.01)$. $H 5$ and $H 6$ are supported.

H1: beliefs $_{t} \rightarrow$ attitude $_{t}$

Beliefs $_{t+1} \rightarrow$ attitude $_{t+1}$

H2: attitude $_{t} \rightarrow$ past behavior $_{t}$

Attitude $_{t+1} \rightarrow$ behavioral intention $_{t+1}$

H3: beliefs $\mathrm{b}_{t} \rightarrow$ beliefs $_{t+1}$

H7: past behavior $\rightarrow$ would $_{t}$

H8: culture $_{t} \rightarrow$ would $_{t}$

H9: Internal resources $t \rightarrow$ could $_{t}$

H1O: external environment ${ }_{t} \rightarrow$ could $_{t}$

H11: personal values $\rightarrow$ should $_{t}$

$0.699 * * *$

$0.470 * * *$

$0.202^{* * * *}$

$0.354^{* * * *}$

$0.500 * * *$

$-0.044^{*}$

$0.063 * *$

$0.699 * * *$

Notes: ${ }^{*} p<0.1 ;{ }^{* *} p<0.05 ;{ }^{* * *} p<0.001$




JSTP

27,3

582

The mediation effect of news was tested and results showed a significant and complete indirect effect of could $\mathrm{e}_{t}$ expectations on attitude toward news ${ }_{t}$ through would expectations $_{t}$ and attitude toward news $t$ fully mediate the effect of would and should $_{t}$ expectations on beliefs about the firm ${ }_{t+1}$, further supporting H4-H6. Moreover, we fitted the model separately for the respondents who saw positive and negative news and found the same model fit both, so we were able to pool the two subsamples.

\subsection{Robustness checks}

We performed robustness checks on the measurement model results. We checked whether the fully mediated model of would $t /$ should $_{t}$ expectations $\rightarrow$ attitude toward news $\rightarrow$ beliefs about firm ${ }_{t+1}$ and would $t$ expectations $\rightarrow$ could $_{t}$ expectations $\rightarrow$ attitude toward news thold for a randomly chosen validated sample. Following the procedures used by Bart et al. (2005), we used two thirds of our sample to estimate the model and one third of our sample to validate the model. We analyzed the differences between the path coefficients from the two samples (assuming invariant factor structure of both calibrated and validated samples). The factor correlations are similar suggesting the predictive validity of the model.

\subsection{Alternative measurement and structural models}

We compared the fit of our hypothesized measurement model with 14 factors (Model 1), with other plausible models - a nested alternative 13-factor Model 2 (combining would , $_{\text {, and }}$ could $_{t}$ expectations) and a 12 -factor Model 3 (combining all three expectations). The results supported that the hypothesized model was the best fit for measuring consumer's expectations. This is an important finding in affirming our proposed model in Figure 1. We also compared the fit of the hypothesized structural model to the two alternative models. The fit statistics provided support that the hypothesized structural model was the best-fitting model to the data. Finally, in addition to the above alternative model tests, we conducted supplementary analyses to explore potential problems of model misspecification. We used traditional regression methods in conjunction with product terms to test for possible interaction effects between attitude toward news $t_{t}$ and beliefs about the firm ${ }_{t+1}$ path. No meaningful interaction effects were observed (Tables V and VI).

\section{Discussion}

Although expectations are widely acknowledged to be an integral part of CSR, their role has not previously been empirically tested in a systematic manner. This study distinguishes three expectation standards - would, could and should - to develop a full model of expectations, explore direct and indirect relationships among expectations, attitude toward news and updated beliefs (and subsequent attitude and behavioral intentions) in a service industry, and identifies the key antecedents of different types of expectations. Previous studies have typically categorized expectations either as predictive or normative standards

Table V.

Alternative measurement models

\begin{tabular}{lccccc}
\hline Alternative measurement model & $\chi^{2}$ & df & CFI & TLI & RMSEA \\
\hline $\begin{array}{l}\text { Model 1 } \\
\text { Hypothesized 14-factor model }\end{array}$ & 67.12 & 12 & 0.959 & 0.941 & 0.050 \\
$\begin{array}{l}\text { Model 2 } \\
\begin{array}{l}\text { 13-factor model (could expectations and would expectations } \\
\text { combined into a single factor) }\end{array}\end{array}$ & 73.12 & 11 & 0.914 & 0.890 & 0.111 \\
$\begin{array}{l}\text { Model 3 } \\
\text { 12-factor model (all three expectations combined as one factor) }\end{array}$ & 71.01 & 11 & 0.893 & 0.847 & 0.190 \\
\hline
\end{tabular}


Alternative structural model

Model 1

Hypothesized structural model

$\begin{array}{llll}67.12 & 12 & 0.951 & 0.946\end{array}$

0.045

Model 2

Beliefs about firm ${ }_{t} \rightarrow$ attitude toward news seliefs about firm $_{t+1}$

$\begin{array}{llll}73.12 & 11 & 0.891 & 0.825\end{array}$

0.113

Model 3

Would $_{t}$, could $t$, should $t$ expectations $\rightarrow$ attitude toward news $t \rightarrow$ beliefs about firm tit $_{1}$

$\begin{array}{llll}71.01 & 11 & 0.853 & 0.812\end{array}$

Model 4

Would $t$, could $_{t}$, should $t$ expectations $\rightarrow$ beliefs about firm ${ }_{t+1}$ $\begin{array}{llll}76.88 & 10 & 0.790 & 0.741\end{array}$
Role of expectations on consumer interpretation

583

Table VI.

Alternative structural model

(Boulding et al., 1993; Cadotte et al., 1987; Swan and Trawick, 1980). However, very few comparative studies look at how consumers may also weigh up the firm's resources and external market conditions to deduce its possible performance when evaluating it (Barney, 1991). Our study takes a step toward resolving this gap by harnessing insights from RBF, and extends the expectations literature by presenting a third set of expectations - could expectations, providing a mechanism by which perceived resources can affect evaluation, as proposed by Hart (1995). Could expectations offer a vehicle for examining how consumers assess resource and external environmental constraints to come up with what a firm would do in the formation of expectations. We have demonstrated the explanatory power of could expectations. Models incorporating all three forms of expectation clearly outperform those with only two (should and would) which in turn outperform the use of one generalized expectations construct. This provides a fundamental challenge to marketing managers to manage consumer perceptions of different expectations' antecedents (both internal resources and the external environment) in order to gain the most advantageous benchmarks against which their performance will be judged.

Next, while previous studies in attitude theorizing indicate that attitudes toward news may vary with the context of a given piece of news such as source credibility (Clow et al., 2011; Wu and Shaffer, 1987) and news media persuasion (Gerber et al., 2011; Gunther, 1992), this study suggests that the effects of consumers' expectations can also significantly influence their attitudes toward a piece of given news. The findings show that attitude toward news fully mediates the observed relations between would and should expectations and updated priors. This has several implications for the management of an airline's communications. First, since it is not possible to control how the media disseminate news about the firm, an understanding of the basis on which expectations are formed should be useful for predicting a consumer's response to a piece of news and hence beliefs about a firm, and shaping it. Second, the mediating findings of would expectations on the relationship between could expectations and attitude toward news suggest that manipulating would expectations may be used to enhance the effects of positive news or mitigate the undesirable effects of negative ones. Moreover, as a complete mediator of the relation between could expectations and attitude toward news, would expectations were apparently the only medium through which the influence of could expectations is felt. These results point to a new and interesting role for the set of expectations constructs. Our recommendation is that, when formulating their CSR news and communication strategies, service providers should be particularly cognizant of the differential importance played by would and should expectations in order to calibrate the impact of news on consumers' preferences.

The findings also identify a weak negative relationship between past behavior and would expectations. This unexpected finding highlights the need for airline managers to pay more attention to their customers in turbulent times because they may decouple 
JSTP

27,3

their positive past experience from what they think the airline is likely to do in the future with respect to CSR. That has happened in the service application studied in this research. It is consistent with research on moral decoupling which has shown that people tend to exhibit a pattern of disassociating CSR transgressions from firm performance (Bhattacharjee et al., 2012). That is, moral decoupling allows consumers to support the performance of firm while simultaneously admonishing the firm's CSR actions. From a marketing point of view, airline managers need to understand how consumers' decoupling might play out in terms of branding and rebranding an airline's image in the face of a controversy situation. Brands that will be most successful are those that can stop consumers' decoupling playing a negative role in the face of positive historical performance (Bhattacharjee et al., 2012).

The results of this study also emphasize the importance of the personal values $\rightarrow$ should expectation formation. Such findings are consistent with Meglino and Ravlin's (1998) observation that a person's pro-social values reflect their beliefs about how one "should" react in response to a set of normative expectations that one endorses. More broadly, the results suggest that values act as a conduit between beliefs and behaviors (Meglino and Ravlin, 1998) and that values influence consumers' should expectations that firms ought to conform to an individual's social norms (Carroll, 1979).

Finally, we examine the antecedents of expectations in a service industry. With growing consumer awareness and expectations of CSR activities (e.g. with regards to environmental degradation), we show that understanding consumers' personal values has significant implications for CSR communications marketing through would expectations (consistent with Dwyer et al., 2009; Pomering and Dolnicar, 2009). For future study, it would be worthwhile testing whether it is possible to replicate the findings using alternative more general measures of values, such as Rokeach's (2000) "universal values," for example.

\subsection{Limitations}

There are a number of limitations associated with this study. First, it is confined to a single legacy carrier. Further research should examine the applicability of the framework by testing it on a broader set of service industries, and of different sizes, or by simultaneously running studies on more than one industry or company. A second potential limitation is that of social desirability bias. In an attempt to provide a "socially appropriate" response, respondents may respond in a manner that is different from their true beliefs. We suggest that this is not a serious threat because the model was measured using different response sets and randomized items (Podsakoff et al., 2003). In addition, we advised respondents that the study is not commercially linked to the focal airline or any commercial entity, and ensured respondents full anonymity, which may help to reduce social desirability bias (Podsakoff et al., 2003). To reduce social desirability pressures in future research of this nature, it may be useful to embed the fabricated CSR news story among a set of other company news stories. Future data collection could include collecting belief measures at two different points of time from the same sample, prior to collecting updated beliefs-attitude-behavioral intention measures. Another approach would be to use alternative methods and measures in an attempt to replicate the results.

\subsection{Future research}

Overall, the findings point to the importance of the consequences of antecedents of expectations in explaining the differential effects of a consumer's would, could and should expectations in response to CSR news. This finding is in line with Oliver's (1980) argument that consumer expectations serve as a standard in the evaluation of satisfaction. The results also provide support for Johnson et al.'s (1995) suggestion that expectations act as an anchor for market-level beliefs because they contain essential information regarding a product's or a firm's past and probable future performance. The overall findings have implications for 
advancing research on expectations and its unique effects on updated beliefs when evaluating more recent news about the airline's CSR activities. In terms of practical implications, especially in service industries, firms that have a good understanding of consumer would, could and should expectations may be well placed to apply marketing strategies that can address consumers' reactions meaningfully. For example, resources could be channeled to understand the potential mediating mechanisms of attitudes toward news and would expectations on the impact of consumer beliefs and behavioral intentions, and to enhance the communication efforts for the firm's CSR initiatives. Avis' "We try harder" communications campaign provides an excellent example of a firm successfully communicating organizational culture to influence would expectations and thus gain more favorable evaluations and higher purchase intent (Parekh, 2012).

Further research with other stakeholders of the firm would be valuable to identify whether the model implied by our study holds for other stakeholders such as travel intermediaries, investors, suppliers, staff and the community at large. We have used CSR as the vehicle with which to identify the antecedents of expectations and the route by which they enter the decision process. It would be useful to test the model we propose on other forms of information integration as well. Additionally, possible non-linear effects of expectations are also worthy of investigation. Finally, expectations about brands within the category will influence and be influenced by expectations about the category itself. It would be useful to build a nested model that links the role of category and brand expectations.

\section{Notes}

1. An analogous survey was also administered simultaneously to QANTAS' travel agent intermediaries to investigate differences between channel and end user evaluation and intent models in the airline industry.

2. The use of a positive and negative news story enables us to test the applicability of our model in both positive and negative news environments, increasing its external validity. See Appendix 5 for their wording.

3. www.abc.net.au/news/2011-10-29/qantas-factbox/3608330

\section{References}

Abbott, B.B. and Bordens, K.S. (1991), Research Design and Methods: A Process Approach, California Mayfield Publishing Company, Mountain View, CA.

Ajzen, I. (1991), "The theory of planned behavior", Organizational Behavior and Human Decision Processes, Vol. 50 No. 2, pp. 179-211.

Bandura, A. (1977), "Self-efficacy: toward a unifying theory of behavioral change", Psychological Review, Vol. 84 No. 2, pp. 191-215.

Barney, J.B. (1986), "Strategic factor markets: expectations, luck, and business strategy", Management Science, Vol. 32 No. 10, pp. 1231-1241.

Barney, J.B. (1991), "Firm resources and sustained competitive advantage", Journal of Management, Vol. 17 No. 1, pp. 99-120.

Bart, Y., Shankar, V., Sultan, F. and Urban, G.L. (2005), "Are the drivers and role of online trust the same for all web sites and consumers? A large-scale exploratory empirical study", Journal of Marketing, Vol. 69 No. 4, pp. 133-152.

Becker-Olsen, K.L., Cudmore, B.A. and Hill, R.P. (2006), "The impact of perceived corporate social responsibility on consumer behavior", Journal of Business Research, Vol. 59 No. 1, pp. 46-53.

Bhattacharjee, A., Berman, J.Z. and Reed, A. II (2012), "Tip of the hat, wag of the finger: how moral decoupling enables consumers to admire and admonish", Journal of Consumer Research, Vol. 39 No. 6, pp. 1167-1184. 
JSTP 27,3

Bhattacharya, C.B., Korschun, D. and Sen, S. (2009), "Strengthening stakeholder-company relationships through mutually beneficial corporate social responsibility initiatives", Journal of Business Ethics, Vol. 85 No. S2, pp. 257-272.

Bhattacharya, C.B., Rao, H. and Glynn, M.A. (1995), "Understanding the bond of identification: an investigation of its correlates among art museum members", The Journal of Marketing, Vol. 59 No. 4, pp. 46-57.

Boulding, W., Kalra, A., Staelin, R. and Zeithaml, V.A. (1993), "A dynamic process model of service quality: from expectations to behavioral intentions", Journal of Marketing Research, Vol. 30 No. 2, pp. 7-27.

Brown, D. (1997), "The company and the product: corporate associations and consumer product responses", The Journal of Marketing, Vol. 61 No. 1, pp. 68-84.

Cadotte, E.R., Woodruff, R.B. and Jenkins, R.L. (1987), "Expectations and norms in models of consumer satisfaction”, Journal of Marketing Research, Vol. 24 No. 3, pp. 305-314.

Carroll, A.B. (1979), "A three-dimensional conceptual model of corporate performance", The Academy of Management Review, Vol. 4 No. 4, pp. 497-505.

Carroll, A.B. and Buchholtz, A.K. (2011), Business and Society: Ethics and Stakeholder Management, South-Western Cengage Publishing, Mason, $\mathrm{OH}$.

Clow, K.E., James, K.E., Sisk, S.E. and Cole, H.S. (2011), "Source credibility, visual strategy and the model in print advertisements", Journal of Marketing Development and Competitiveness, Vol. 5 No. 3, pp. 24-31.

Cone (2013), "Cone communications social impact study", Cone Communications, available at: www.conecomm.com/stuff/contentmgr/files/0/e3d2eec1e15e858867a5c2b1a22c4cfb/files/2013_ cone_comm_social_impact_study.pdf (accessed July 9, 2016).

Creyer, E.H. and Ross, W.T. (1997), "The influence of firm behavior on purchase intention: do consumers really care about business ethics?”, Journal of Consumer Marketing, Vol. 14 No. 6, pp. 421-432.

Danaher, P.J., Roberts, J.H., Roberts, K. and Simpson, A. (2011), "Practice prize paper - applying a dynamic model of consumer choice to guide brand development at Jetstar Airways", Marketing Science, Vol. 30 No. 4, pp. 586-594.

de Vries, M.F.R.K. and Miller, D. (1986), "Personality, culture, and organization”, Academy of Management Review, Vol. 11 No. 2, pp. 266-279.

Dezenhall, E. and Weber, J. (2011), Damage Control: The Essential Lessons of Crisis Management, Easton Studio Press, LLC, Westport.

Donaldson, T. and Preston, L.E. (1995), "The stakeholder theory of the corporation: concepts, evidence, and implications", Academy of Management Review, Vol. 20 No. 1, pp. 65-91.

Du, S., Bhattacharya, C.B. and Sen, S. (2010), "Maximizing business returns to corporate social responsibility (CSR): the role of CSR communication”, International Journal of Management Reviews, Vol. 12 No. 1, pp. 8-19.

Dwyer, L., Edwards, D., Mistilis, N., Roman, C. and Scott, N. (2009), "Destination and enterprise management for a tourism future”, Tourism Management, Vol. 30 No. 1, pp. 63-74.

Epstein-Reeves, J. (2010), “Consumers overwhelmingly want CSR”, Forbes, December 10, p. 1, available at: www.forbes.com/sites/csr/2010/12/15/new-study-consumers-demand-companies-implementcsr-programs/\$649ab4b05e1d (accessed July 9, 2016).

Fishbein, M. and Ajzen, I. (1975), Belief, Attitude, Intention and Behavior: An Introduction to Theory and Research, Addison Wesley Publishing, Reading, MA.

Fiske, S.T. and Nueberg, S.L. (1990), "A continuum of impression formation, from category-based to individuating processes: influences of information and motivation on attention and interpretation", Advances in Experimental Social Psychology, Vol. 23 No. 1, pp. 1-74.

Freeman, R.E. (1984), Strategic Management: A Stakeholder Approach, Pitman/Ballington, Boston, MA.

Friedman, M. (1970), "The social responsibility of business is to increase its profits", in Silverstein, J. (Ed.), Corporate Ethics and Corporate Governance, Arthur Ochs-Sulzberger and New York Times Magazine, New York, NY, pp. 173-178. 
Gerber, A.S., Gimpel, J.G., Green, D.P. and Shaw, D.R. (2011), "How large and long-lasting are the persuasive effects of televised campaign ads? Results from a randomized field experiment", American Political Science Review, Vol. 105 No. 1, pp. 135-150.

Goldsmith, R.E., Flynn, L.R. and Bonn, M. (1994), “An empirical stud of heavy users of travel agencies”, Journal of Travel Research, Vol. 33 No. 1, pp. 38-43.

Grewal, R., Cote, J.A. and Baumgartner, H. (2004), "Multicollinearity and measurement error in structural equation models: implications for theory testing", Marketing Science, Vol. 23 No. 4, pp. 519-529.

Gunther, A.C. (1992), "Biased press or biased public? Attitudes toward media coverage of social groups", Public Opinion Quarterly, Vol. 56 No. 2, pp. 147-167.

Hair, J.F., Anderson, R.E., Tatham, R.L. and Black, W.C. (1995), Multivariate Data Analysis, Prentice-Hall Inc., New York, NY.

Hart, S.L. (1995), “A natural-resource-based view of the firm”, Academy of Management Review, Vol. 20 No. 4, pp. 986-1014.

Herzberg, F., Mausner, B. and Snyderman, B. (2011), The Motivation to Work, Vol. 1, Transaction Publishers, New Brunswick.

Ho, A., Sharma, P. and Hosie, P. (2015), "Exploring customers' zone of tolerance for B2B professional service quality", Journal of Services Marketing, Vol. 29 No. 5, pp. 380-392.

Homburg, C., Stierl, M. and Bornemann, T. (2013), "Corporate social responsibility in business-tobusiness markets: how organizational customers account for supplier corporate social responsibility engagement”, Journal of Marketing, Vol. 77 No. 6, pp. 54-72.

Hume, D. (1978), A Treatise of Human Nature, in Selby-Bigge, L.A. (Ed.), revised by P.H. Nidditch, Vol. 2, Clarendon Press, Oxford.

Iacobucci, D., Saldanha, N. and Deng, X. (2007), "A meditation on mediation: evidence that structural equations models perform better than regressions", Journal of Consumer Psychology, Vol. 17 No. 2, pp. 139-153.

Ioannou, I. and Serafeim, G. (2015), "The impact of corporate social responsibility on investment recommendations: analysts' perceptions and shifting institutional logics”, Strategic Management Journal, Vol. 36 No. 7, pp. 1053-1081.

James, O. (2009), "Evaluating the expectations disconfirmation and expectations anchoring approaches to citizen satisfaction with local public services", Journal of Public Administration Research and Theory, Vol. 19 No. 1, pp. 107-123.

Johnson, M.D., Anderson, E.W. and Fornell, C. (1995), "Rational and adaptive performance expectations in a customer satisfaction framework", Journal of Consumer Research, Vol. 21 No. 4, pp. 695-707.

Johnston, R. (2004), "Towards a better understanding of service excellence", Managing Service Quality: An International Journal, Vol. 14 Nos 2/3, pp. 129-133.

Kahneman, D. and Miller, D.T. (1986), "Norm theory: comparing reality to its alternatives", Psychological Review, Vol. 93 No. 2, pp. 136-153.

Klein, J. and Dawar, N. (2004), "Corporate social responsibility and consumers' attributions and brand evaluations in a product-harm crisis", International Journal of Research in Marketing, Vol. 21 No. 3, pp. 203-217.

Klein, J., Smith, N.C. and John, A. (2004), "Why we boycott: consumer motivations for boycott participation”, Journal of Marketing, Vol. 68 No. 3, pp. 92-109.

Korschun, D., Bhattacharya, C.B. and Swain, S.D. (2014), "Corporate social responsibility, customer orientation, and the job performance of frontline employees", Journal of Marketing, Vol. 78 No. 3, pp. 20-37.

Kull, A.J., Mena, J.A. and Korschun, D. (2016), “A resource-based view of stakeholder marketing”, Journal of Business Research, Vol. 69 No. 12, pp. 5553-5560.

Lii, Y.S. and Lee, M. (2012), "Doing right leads to doing well: when the type of CSR and reputation interact to affect consumer evaluations of the firm”, Journal of Business Ethics, Vol. 105 No. 1, pp. 69-81. 
JSTP 27,3

Lindell, M.K. and Whitney, D.J. (2001), "Accounting for common method variance in cross-sectional research designs", Journal of Applied Psychology, Vol. 86 No. 1, pp. 114-121.

Luo, X. and Bhattacharya, C.B. (2006), "Corporate social responsibility, customer satisfaction, and market value", Journal of Marketing, Vol. 70 No. 4, pp. 1-18.

McKercher, B., Packer, T., Yau, M.K. and Lam, P. (2003), “Travel agents as facilitators or inhibitors of travel: perceptions of people with disabilities", Tourism Management, Vol. 24 No. 4, pp. 465-474.

McPherson, S. (2016), " 5 CSR trends that will blossom in 2016", Forbes, January 8, pp. 1-2, available at: www.forbes.com/sites/susanmcpherson/2016/01/08/5-csr-trends-that-will-blossom-in-2016/ $\sharp 6 d 4315 b 1742 a$ (accessed July 9, 2016).

Manheim, J.B. and Albritton, R.B. (1984), "Changing national images: international public relations and media agenda setting”, The American Political Science Review, Vol. 78 No. 3, pp. 641-657.

Mather, M. and Johnson, M.K. (2000), "Choice-supportive source monitoring: do our decisions seem better to us as we age?", Psychology and Aging, Vol. 15 No. 4, pp. 596-606.

Meglino, B.M. and Ravlin, E.C. (1998), "Individual values in organizations: concepts, controversies, and research", Journal of Management, Vol. 24 No. 3, pp. 351-389.

Miller, D. and Friesen, P.H. (1983), "Strategy-making and environment: the third link", Strategic Management Journal, Vol. 4 No. 3, pp. 221-235.

Miller, J.A. (1977), "Studying satisfaction, modifying models, eliciting expectations, posing problems, and making meaningful measurements", in Keith Hunt, H. (Ed.), Conceptualization and Measurement of Consumer Satisfaction and Dissatisfaction, Indiana University, Bloomington, IN, pp. 72-91.

Oliver, O.L. (1980), "A cognitive model of the antecedents and consequences of satisfaction decisions", Journal of Marketing Research, Vol. 17 No. 4, pp. 460-469.

Olkkonen, L. and Luoma-aho, V. (2014), "Public relations as expectation management?", Journal of Communication Management, Vol. 18 No. 3, pp. 222-239.

Olson, J.C. and Dover, P.A. (1979), "Disconfirmation of consumer expectations through product trial", Journal of Applied Psychology, Vol. 64 No. 2, pp. 179-189.

Parasuraman, A., Zeithaml, V.A. and Berry, L.L. (1994), "Reassessment of expectation as comparison standard in measuring service quality: implications for future research", Journal of Marketing, Vol. 58 No. 1, pp. 11-24.

Parekh, R. (2012), "After 50 years, Avis drops iconic 'we try harder' tagline” AdAge, August 27, available at: http://adage.com/article/news/50-years-avis-drops-iconic-harder-tagline/236887/ (accessed August 28, 2016).

Podsakoff, P.M., MacKenzie, S.B., Lee, J.Y. and Podsakoff, N.P. (2003), "Common method biases in behavioral research: a critical review of the literature and recommended remedies", Journal of Applied Psychology, Vol. 88 No. 5, pp. 879-903.

Polo, Y. and Sese, F.J. (2013), "Strengthening customer relationships: what factors influence customers to migrate to contracts?", Journal of Service Research, Vol. 16 No. 2, pp. 138-154.

Pomering, A. and Dolnicar, S. (2009), "Assessing the prerequisite of successful CSR implementation: are consumers aware of CSR initiatives?”, Journal of Business Ethics, Vol. 85, Supplement 6, pp. 285-301.

Prakash, V. (1984), "Validity and reliability of the confirmation of expectations paradigm as a determinant of consumer satisfaction", Journal of the Academy of Marketing Science, Vol. 12 No. 4, pp. 63-76.

Preacher, K.J. and Hayes, A.F. (2008), "Asymptotic and resampling strategies for assessing and comparing indirect effects in multiple mediator models", Behavior Research Methods, Vol. 40 No. 3, pp. 879-891.

Raghubir, P., Roberts, J.H., Lemon, K.N. and Winer, R.S. (2010), “Why, when and how should the effect of marketing be measured? A stakeholder perspective for corporate social responsibility metrics", Journal of Public Policy and Marketing, Vol. 68 No. 4, pp. 16-32. 
Richards, L. (1999), Using NVivo in Qualitative Research, Sage Publications, New York, NY.

Roberts, J.H. and Urban, G.L. (1988), "Modeling multiattribute utility, risk, and belief dynamics for new consumer durable brand choice", Management Science, Vol. 34 No. 2, pp. 167-185.

Rokeach, M. (1968), Beliefs, Attitudes, and Values: A Theory of Organization and Change, The Free Press, New York, NY.

Rokeach, M. (2000), Understanding Human Values: Individual and Societal, The Free Press, New York, NY.

Rossiter, J.R. (2002), “The C-OAR-SE procedure for scale development in marketing”, International Journal of Research in Marketing, Vol. 19 No. 4, pp. 305-335.

Russo, M.V. and Fouts, P.A. (1997), "A resource-based perspective on corporate environmental performance and profitability", The Academy of Management Journal, Vol. 40 No. 3, pp. 534-559.

Sachdev, S.B. and Verma, H.V. (2002), "Customer expectations and service quality dimensions consistency: a study of select industries", Journal of Management Research, Vol. 2 No. 1, pp. 43-52.

Sachdev, S.B. and Verma, H.V. (2004), "Relative importance of service quality dimensions: a multisectoral study", Journal of Services Research, Vol. 4 No. 1, pp. 93-116.

Saunders, S.G. (2015), "Service employee evaluations of customer tips: an expectations- disconfirmation tip gap approach", Journal of Service Theory and Practice, Vol. 25 No. 6, pp. 796-812.

Shaw, D., Grehan, E., Shiu, E., Hassan, L. and Thomson, J. (2005), “An exploration of values in ethical consumer decision making”, Journal of Consumer Behaviour, Vol. 4 No. 3, pp. 185-200.

Smith, N.C., Drumwright, M.E. and Gentile, M.C. (2010), “The new marketing myopia”, Journal of Public Policy and Marketing, Vol. 29 No. 1, pp. 4-11.

Srivastava, R.K., Fahey, L. and Christensen, H.K. (2001), "The resource-based view and marketing: the role of market-based assets in gaining competitive advantage", Journal of Management, Vol. 27 No. 6, pp. 777-802.

Steenkamp, J.-B.E.M. and Van Trijp, H. (1991), "The use of LISREL in validating marketing constructs", International Journal of Research in Marketing, Vol. 8 No. 4, pp. 283-299.

Strombeck, S. and Shu, S.T. (2014), "Modeling contextually elicited service quality expectations", Managing Service Quality, Vol. 24 No. 2, pp. 160-183.

Swan, J.E. and Trawick, I.F. (1980), Satisfaction Related to Predictive vs Desired Expectations, Refining Concepts and Measures of Consumer Satisfaction and Complaining Behavior, School of Business, Indiana University, Bloomington, IN, pp. 7-12.

Tabachnick, B.G., Fidell, L.S. and Osterlind, S.J. (2001), Using Multivariate Statistics, Pearson Education Ltd, London.

Tan, L. (2013), "The effects of stakeholders' expectations in their evaluation of corporate social responsibility news", unpublished $\mathrm{PhD}$ thesis, Australian National University, Canberra.

Teas, R.K. (1993), "Expectations, performance evaluation, and consumers' perceptions of quality", The Journal of Marketing, Vol. 57 No. 4, pp. 18-34.

Trice, H.M. and Beyer, J.M. (1984), "Studying organizational cultures through rites and ceremonials", Academy of Management Review, Vol. 9 No. 4, pp. 653-669.

Tripsas, M. and Gavetti, G. (2000), "Capabilities, cognition and inertia: evidence from digital imaging”, Strategic Management Journal, Vol. 21 Nos 10-11, pp. 1147-1161.

Tse, D.K. and Wilton, P.C. (1988), "Models of consumer satisfaction formation: an extension”, Journal of Marketing Research, Vol. 25 No. 2, pp. 204-212.

Tversky, A. and Kahneman, D. (1974), "Judgment under uncertainty: heuristics and biases", Science, Vol. 185 No. 4157, pp. 1124-1131.

Urban, G.L. and Karash, R. (1971), "Evolutionary model building”, Journal of Marketing Research, Vol. 8 No. 1, pp. $62-66$.

Vallaster, C., Lindgreen, A. and Maon, F. (2012), "Strategically leveraging corporate social responsibility”, California Management Review, Vol. 54 No. 3, pp. 34-60. 
JSTP

27,3

Weiner, B. (1985), "An attributional theory of achievement motivation and emotion", Psychological Review, Vol. 92 No. 4, pp. 548-573.

Wernerfelt, B. (1984), “A resource-based view of the firm”, Strategic Management Journal, Vol. 5 No. 2, pp. 171-180.

Wu, C. and Shaffer, D.R. (1987), "Susceptibility to persuasive appeals as a function of source credibility and prior experience with the attitude object", Journal of Personality and Social Psychology, Vol. 52 No. 4, pp. 677-688.

Yuksel, A. and Rimmington, M. (1998), "Customer-satisfaction measurement”, Cornell Hospitality Quarterly, Vol. 39 No. 6, pp. 60-70.

Zeithaml, V.A. (2002), "Service excellence in electronic channels", Managing Service Quality: An International Journal, Vol. 12 No. 3, pp. 135-139.

Zeithaml, V.A., Berry, L.L. and Parasuraman, A. (1993), "The nature and determinants of customer expectations of service", Journal of the Academy of Marketing Science, Vol. 21 No. 1, pp. 1-12.

\section{Appendix 1. Semi-structured interview guidelines}

Appendices provide the methodology used to develop the questionnaire items (Appendices 1 and 2), undertake respondent solicitation (Appendix 3), the survey instrument (Appendix 4) and the positive and negative news stimuli (Appendix 5). They provide the preliminary analysis before the structural equation model reported in the paper was fit; factor loadings of items on constructs (Table AII), the distribution of factor scores (Appendix 7), moments of the survey items underlying the constructs, including means and standard errors (Appendix 8), and the results of fitting the measurement model (Appendix 9).

\section{Interview discussion guide}

Thank you very much for agreeing to talk with us. The study aims to fill the current knowledge and capacity gap on stakeholders' perception of airlines. Qantas has been chosen as one of the selected airlines as part of this research to document, and analyze travel air passengers' beliefs, attitude, behavior and general expectations of airlines.

Section 1. Demographic

Air passengers

- How many times have you traveled via plane over the last 12 months?

- How have you traveled in the past 12 months? (Economy, Business, First Class).

- What is the purpose of your travel over the past 12 months? Business or personal?

- What are some of your key considerations when choosing an airline?

- Speed of service, efficiency of check-in staff, attitude of check-in staff, cabin crew, Reading material, toilet facilities.

- Price, routes, timing of arrival and departure.

- Baggage reclaiming.

- Aircraft (Cleanliness, Comfort, Leg room, Air quality, Cabin temperature, Entertainment facilities).

- Disembarking procedures.

\section{Section 2. Beliefs/Attitude/Behavior}

What in your view makes a good/ poor airline?

Can you give me some examples? What did they do?

How do you derive this knowledge from? 
How do you feel about this?

What kind of factors do you take into account when deciding on a particular airline?

Do you have any specific airlines you would highly recommend to your family/friends?

Can you explain why?

\section{Section 3. CSR}

Airline CSR (explain CSR first). With reference to airlines' CSR, what comes to your mind?

What kind of activities do you relate to airlines CSR?

Do you know of any airlines who engage in (CSR activity)?

Can you recall the specifics of this CSR activity of this airline?

CSR news. What kinds of CSR news do you normally hear/read/learn about airlines? (Donation, pilot strikes, crashes, donation, downsizing, financial losses, fuel costs increases, employee disputes, etc.)

From which source do you normally hear/read/learn about airlines CSR-related news?

Is there a specific reason why you remember this news?

Would you explain further?

Personal values. With reference to the (CSR activity) that you have mentioned, do you think the public will support it? Why?

What do you think should have been done in this instance?

Can you elaborate on that?

What would you say to the criticism that airlines are...?

\section{Section 4. Knowledge of airline}

Airlines' culture. On what matters do you contact the airlines for? (Ticketing restrictions, e-ticketing issue, etc.).

Can you explain to me why (ticketing restrictions, e-ticketing issue, etc.) is important?

What, in your view are some of the factors that affect the airlines' ability to provide the expected services?

What do you think is the cause of better/poorer services?

Can you give me some examples?

In your view, is there any difference with the services provided by (x) airline when compared to (y) airlines? Why do you say so?

Resources. Continue - You mentioned (management). Why do you think (management) can affect the airlines ability to deliver better/poorer CSR?

Can you give me some examples?

Do you think this common airline practice/ phenomenon? Can you give me some examples?

Can you suggest other factors that in your view might affect an airline's ability to engage in (CSR)? 
Qantas is constantly improving

Qantas has a stable business

Qantas is a trouble-free airline

Qantas is not as good as it was three years ago

Qantas flights run on-time

When I have a problem, Qantas is sympathetic and reassuring

Qantas promptly informs me of my booked flight delays

Employees of Qantas are always willing to help me with my needs

Qantas employees care how I feel

Employees of Qantas know what my needs are

Qantas has my best interest at heart

Qantas gives me attention

Supports local communities

Contributes to environment pollution reduction

Cares about its employees' welfare

Encourages corporate giving to worthy causes

I think Qantas is a great airline

I admire Qantas

I trust Qantas

I like Qantas very much

I choose Qantas as my first choice whenever possible

I speak highly of Qantas to other people

I defend the actions of Qantas whenever possible

I encourage friends and relatives to fly with Qantas

being people oriented

being fair

being supportive

respecting individual rights

desiring to be a good corporate citizen

caring about the community it serves

focusing and solving customer problems

caring more about financial results than service delivery

feeling oppressed/ constrained by environmental forces in the global aviation market

Has the financial capacity to run a great airline

Has the resources to help reduce environmental pollution

Is strong enough to make a positive contribution to the local economy

Has support from the local community

Has a CEO known for his support of corporate social responsible initiatives

Employees take pride in what they do

Employees are committed to their work

The airline industry is struggling to survive

High fuel costs globally present a problem for Qantas

High Australian dollars is a disadvantage to Qantas

Qantas faces a hostile union locally

Competition from other airlines is affecting Qantas' business

Qantas faces very strong government regulations locally

Table AI.

Content validity

The general public is increasingly dissatisfied with Qantas
23

21

25

23

25

23

25

24

22

21

21

21

24

22

25

23

25

23

25

24

24

24

23

23

25

25

21

25

23

23

21

25

23

25

23

20

25

25

24

23

25

24

25

25

25

25

25
0.84

0.68

1

0.84

1

0.84

1

0.92

0.76

0.68

0.68

0.68

0.92

0.76

1

0.84

1

0.84

1

0.92

0.92

0.92

0.84

0.84

1

1

0.68

1

0.84

0.84

0.68

1

0.84

1

0.84

0.6

1

0.92

0.84

1

0.92

1

1

rationale for items in questionnaire 
Useful, but

Not

The media is critical of Qantas

Support charities and social services projects

Ensure that products and operations do not harm the environment

Treat all employees equally regardless of gender, race religion or sexuality

Improve education and skills in communities where they operate Not only protect the environment but also restore it for future generations

Ensure that all materials it uses to make its products have been

Play a role in our society that goes beyond the mere generation of profits

Should support works to help the disadvantaged in society

Should undertake actions to defend (protect) the environment

Should make donations to worthy causes of social justices such as education

Should support organizations that defend culture and sports

Should support adequate employee welfare such as better

working conditions

Should care about more than its profit and financial performance

Could support works to help the disadvantaged in society

Could undertake actions to defend (protect) the environment

Could make donations to worthy causes of social justices such as education

Could support adequate employee welfare such as better working conditions

Could care about more than its profit and financial performance

Would support works to help the disadvantaged in society

Would undertake actions to defend (protect) the environment

Would make donations to worthy causes of social justices such as education

Would support organizations that defend culture and sports

Would support adequate employee welfare such as better working conditions

Would care about more than its profit and financial performance

I regard this as good news

I am pleasantly surprised by this news

I would describe this news as positive

I am overall pleased with what I have read
Essential not essential necessary CVR

24
25
25
25
21

24
25
25
21

1

0

0
0

(

0

4

22

24

$\begin{array}{ll}0 & 0.92\end{array}$

$\begin{array}{ll}0 & 1 \\ 0 & 1\end{array}$

1
1
1

\section{interpretation}

0

593

1

0

0.68

0.76

$3 \quad 0$

$\begin{array}{lll}0 & 0 & 1\end{array}$

0.92

10

0

0

$0 \quad 0.84$

0.76

0

$0 \quad 1$

$\begin{array}{ll}0 & 1 \\ 0 & 0.92\end{array}$

0

0.92

0.84

$\begin{array}{ll}0 & \\ 0 & 1\end{array}$

$\begin{array}{ll}0 & 0.92 \\ 0 & 0.84\end{array}$

$0 \quad 1$

$\begin{array}{ll}1 & 0.92 \\ & 0.92\end{array}$

$\begin{array}{lll}1 & 0 & \\ 1 & 0 & 0.92 \\ 2 & 0 & 0.84 \\ 1 & 0 & 0.92 \\ 0 & 0 & 1 \\ 1 & 0 & 0.92\end{array}$

Table AI. 


\section{E-mail invitation to respondents}

\section{University Letterhead}

\section{Dear [NAME],}

I am writing to request your help with an important project in the travel industry. The university is conducting a survey of travel professionals to ask about their perception of airlines' service dimensions. Your participation is critical to the success of this project. Only through your responses, can we better understand the travel professionals' perception of the Australian aviation industry and help major carriers to better serve the stakeholders like yourself. The survey should not take more than 10 minutes of your time and I think that you will find it interesting. Your answers are will be kept confidential. Your name or identity will not be linked in any way to the research data. However, if you are interested in a copy of the aggregate results, we would be happy to share them with you.

To participate in our survey, please click on the link:

https://www.surveymonkey.com/s/Airline TAP and you can go into the draw for AUD $\$ 500$ retail voucher of your choice (or donate $A \cup \$ 500$ to charity).

Thank you in advance for your participation in this important project. If you have any questions about the purpose or administration of the survey, please contact $x x x$ or $x x x$ email: xxx@xxx.com at tel: +xxxxxxxx

Thank you once again.

Professor [Author name] 
*1. I have read and understood the above statements, and have decided to take part in the study.

$$
\begin{aligned}
& \text { I agree } \\
& \text { I idsagree }
\end{aligned}
$$

We are interested in understanding your perception and views as a travel professional in Australia. There are no right or wrong answers. The score you choose should just reflect your perceptions about this airline. This survey has NO COMMERCIAL LINKS with any airline or commercial entity

*2. To what extent do you agree with the following statements about this airline's reputation?

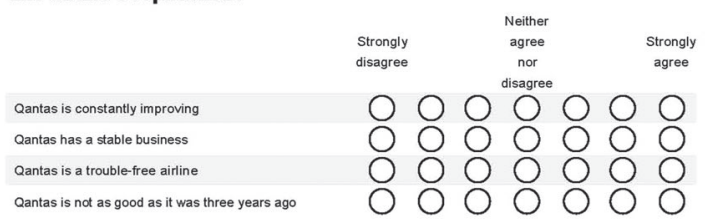

*3. To what extent do you agree with the following statements about Qantas' service delivery?

Qantas flights run on-time

When I have a problem, Qantas is sympathetic and

reassuring

Qantas prompty informs my customers of their booked

flight delays

Employees of Qantas are always willing to help me with

$\begin{array}{lcc} & \text { Neither } & \\ \text { Strongly } & \text { agree } & \text { Strongly } \\ \text { disagree } & \text { nor } & \text { agree }\end{array}$

my needs

*4. To what extent do you agree with the following statements about how Qantas treats its trade/ travel professionals like yourself?

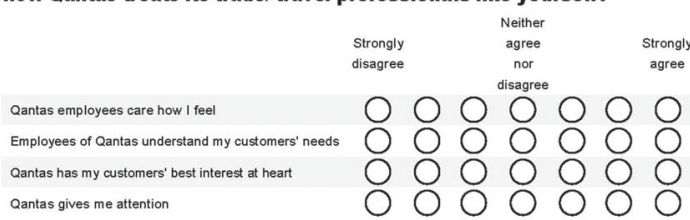


JSTP

27,3

*5. Overall I feel that Qantas as a company:

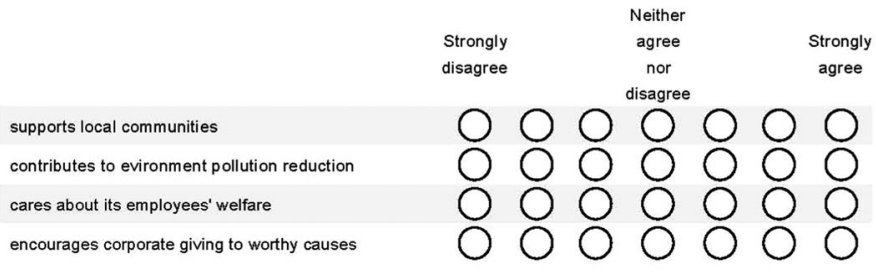

*6. Please tell us how do you feel about Qantas, given your past experience or knowledge about this airline.

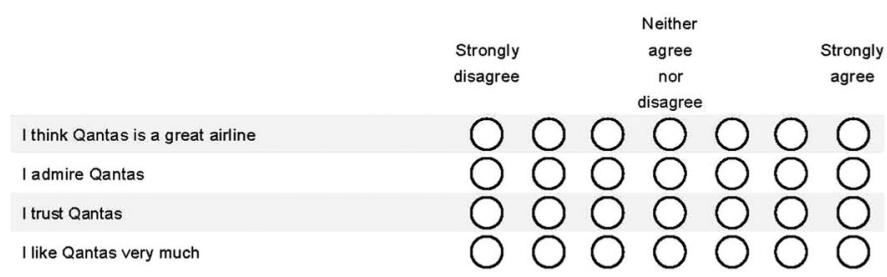

*7. To what extent do you agree with the following statements about yourself with regards to QANTAS?

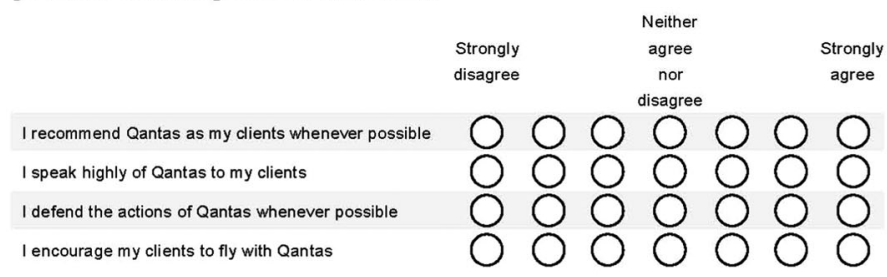

* 8. In my view, I think the following characteristics are part of Qantas' corporate culture:

..being people oriented
$\ldots$..being fair
...being supportive
$\ldots$..especting individual rights
....esiring to be a gooding about the community it serves
...caring moring and solving customer problems
delivery
...feeling oppressed/ constrained by environmental
forces in the global aviation market


*9. I personally think that QANTAS:

has the financial capacity to run a great airline
has the resources to help reduce environmental
pollution (e.g. invest in fuel-efficient aircrafts)
is strong enough to make a positive contribution to the
local economy
has a brand that people respect
has support from the local community
has a CEO known for his support of corporate social
responsible initiatives
employees take pride in what they do
employees are committed to their work

Role of expectations on consumer interpretation

\section{*10. In my view, I think that:}

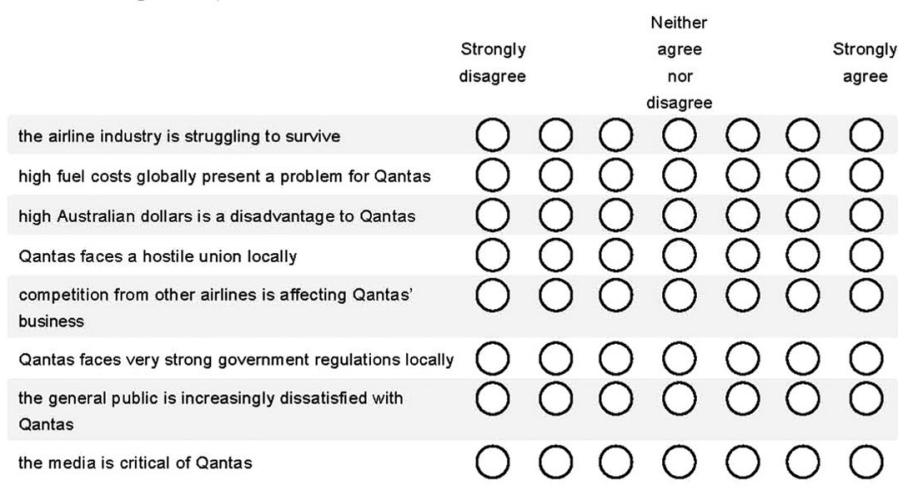

*11. I personally believe that firms have a responsibility to:

support charities and social services projects
ensure that products and operations do not harm the
environment
treat all employees equally regardless of gender, race
religion or sexuality
improve education and skills in communities where they
operate
not only protect the environment but also restore it for
future generations
ensure that all materials it uses to make its products
have been produced in a responsible manner
play a role in our society that goes beyond the mere
generation of profits


JSTP

27,3

\section{8}

Qantas management has a number of decisions to make on its future staffing and business policies. We are interested in your views on the appropriateness of some of its options. There are no right or wrong answers. The score you choose should just reflect your feelings about this airline.

\section{*12. What in your view are Qantas' appropriate actions in Australia?}

\section{Qantas SHOULD dedicate part of its activity to:}

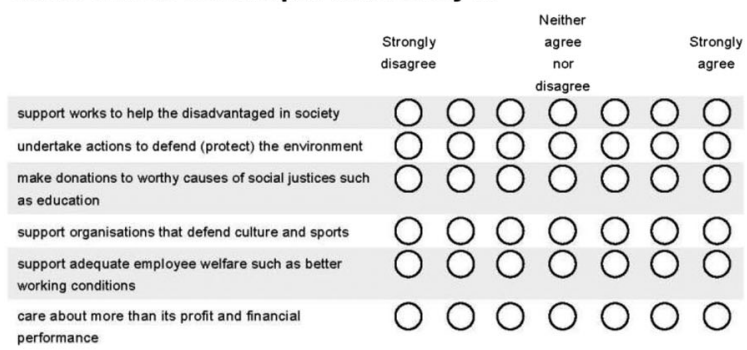

*13. What in your view are Qantas' capability as a company with regards to its corporate social responsibility role in Australia?

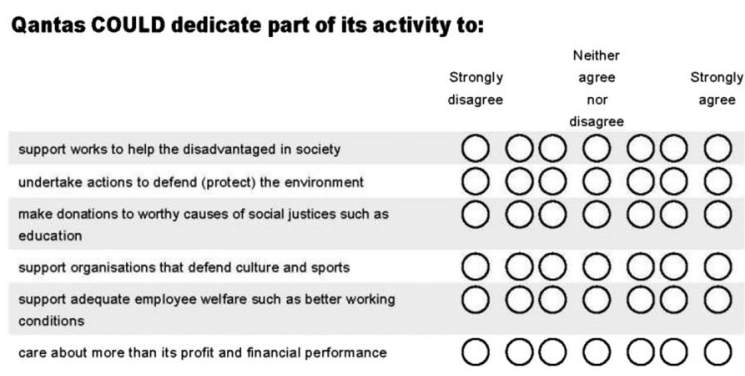


Role of

*14. What in your view are Qantas' likely decisions with regard to its expectations corporate actions in Australia?

Qantas WOULD dedicate part of its activity to:

support works to help the disadvantaged in society
undertake actions to defend (protect) the environment
make donations to worthy causes of social justices such
as education
support organisations that defend culture and sports
$\begin{aligned} & \text { support adequate employee welfare such as better } \\ & \text { working conditions } \\ & \text { care about more than its profit and fin ancial } \\ & \text { performance }\end{aligned}$

Please read the following news about Qantas. Once you have finished reading the news, please proceed with the remaining questions.

$$
\begin{aligned}
& \text { Qantas says corporate social responsibility must follow adequate profitable returns } \\
& \text { Qantas announced yesterday that in an effort to make itself more accountable to its shareholders, it was going to de-emphasise } \\
& \text { all corporate social responsibility initiatives such as better working conditions for its employees, environmental pollution } \\
& \text { reductions, and engaging with local communities until its new international operations is able to generate profitable returns. } \\
& \text { A Qantas spokesperson said that it made no sense to talk ramping up corporate social responsibility until the financial profitability } \\
& \text { of the airline could be ensured. That places Qantas in contrast with its major rivals, British Airways and United, both of which have } \\
& \text { stated that they intended to continue focusing on corporate social responsibility initiatives and that they do not see this as } \\
& \text { incompatible with the need to ensure a reasonable return to shareholders. }
\end{aligned}
$$

*15. Please tell us how you would rate the news. There are no right and wrong answers. The score you choose should truly reflect your feelings about the news.

I regard this as good news


JSTP

27,3

600
*16. To what extent do you agree with the following statements about Qantas' service delivery after reading the news.

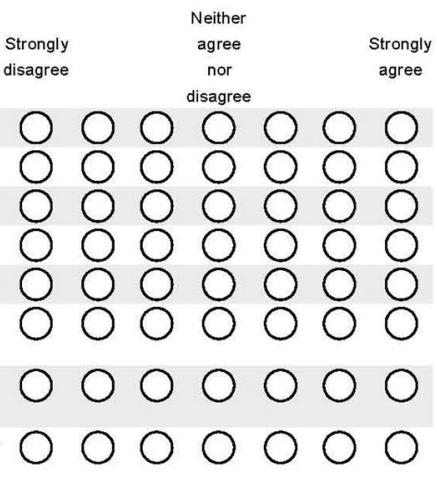

Qantas is constantly improving
Qantas has a stable business
Qantas is a trouble-free airline
Qantas is not as good as it was thrights run on-time years ago
When I have a problem, Qantas is sympathetic and
Qantas pring
flight delays
Employees of Qantas are always willing to help me with
my needs

\section{*17. To what extent do you agree with the following statements}

about Qantas' customer service after reading the news?



*18. Overall I think that Qantas as a company:




Role of

* 19. Please tell us about your attitude towards QANTAS right now. expectations There are no right or wrong answers.

I think Qantas is a great airline
I admire Qantas
I trust Qantas
on consumer interpretation

*20. To what extent do you agree with the following statements about yourself with regards to QANTAS?

I will recommend Qantas to my customers whenever
possible
I will speak highly of Qantas to my customers
I will encourage my customers to fly with Qantas

*21. To what extent do you agree with the following statements about the news you have just read?

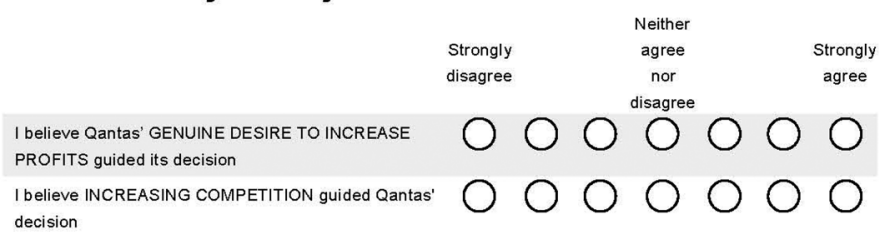

*22. The news article that you have read is about:

QANTAS decreasing its social responsibility initiatives

Has nothing to do with Qantas' corporate social responsibility

Please tell us about yourself. All data collected will be kept confidential and anonymous.

*23. Gender:

Male

Female 
JSTP

27,3

*24. Age:

20 or below

$\mathrm{O}_{41-45}$

21-25

46-50

26-30

51-55

31-35

over 55

602

(36-40

*25. You are

of this travel firm

an employee

the owner/ director

an external consultant

a freelancer

*26. What is your main business activity (activities)? (Tick as many as apply)

$\square$ travel agent

$\square$ wholesaleri ticket consolidator

$\square$ inbound tour operator

$\square$ outbound tour operator

$\square$ online travel agent

27. Would you like a summary copy of the survey's findings?

Yres

No

*28. Would you like to enter for the AU\$500 voucher draw?

$\bigcirc$ Yes, please enter me for the prize draw of AUS $\$ 500$ retail voucher (of my choice)

Yes, please enter me for the prize draw of AUSs500 donation (to a charity of my choice)

No, I do not want to enter for the prize draw

29. If you answer YES to qestion 27 or 28 , please enter your contact email here.

If you win a prize, ANU will pass your email address to RSM institution so your prize token can be emailed to you. (Please note: The institution will not be able to identify you from responses).

My preferred contact email is: 
Appendix 5. News stimuli

The stimulus is a news write-up about the focal airline's CSR policy, with manipulated information about the context of its CSR policy.

\section{Positive news}

Qantas aims to reward its stakeholders

Qantas announced yesterday that in an effort to make itself more accountable to its different stakeholder groups, it was going to base more of its crews in Australia honoring what it saw as its obligations to staff. At the same time Qantas said that it was going to reduce its environmental footprint by using more fuel-efficient planes and having an environmental offset policy. Qantas also indicated that it had plans to help engage and build the communities it serves, both in Australia and overseas. That places Qantas in contrast with its major rivals, British Airways and United, both of which have stated that they intended to balance corporate social responsibility initiatives with the need to ensure a reasonable return to shareholders.

\section{Negative news}

Qantas says corporate social responsibility must follow adequate profitable returns

Qantas announced yesterday that in an effort to make itself more accountable to its shareholders, it was going to de-emphasize all corporate social responsibility initiatives such as better working conditions for its employees, environmental pollution reductions, and engaging with local communities until its new international operations is able to generate profitable returns.

A Qantas spokesperson said that it made no sense to talk ramping up corporate social responsibility until the financial profitability of the airline could be ensured. That places Qantas in contrast with its major rivals, British Airways and United, both of which have stated that they intended to continue focusing on corporate social responsibility initiatives and that they do not see this as incompatible with the need to ensure a reasonable return to shareholders.

\section{Role of expectations on consumer interpretation}

603 
JSTP

27,3

604

\section{Appendix 6}

Beliefs about the firm

Qantas is constantly improving

Qantas has a stable business

Qantas is a trouble-free airline

Qantas is not as good as it was three years ago

Qantas flights run on-time

When I have a problem, Qantas is sympathetic and reassuring

Qantas promptly informs me of my booked flight delays

Employees of Qantas are always willing to help me with my needs

Qantas employees care how I feel

Employees of Qantas know what my needs are

Qantas has my best interest at heart

Qantas gives me attention

supports local communities

contributes to environment pollution reduction

cares about its employees' welfare

encourages corporate giving to worthy causes

Attitude toward the firm $t$

I think Qantas is a great airline

I admire Qantas

I trust Qantas

I like Qantas very much

Past behavior toward the firm

I choose Qantas as my first choice whenever possible

I speak highly of Qantas to other people

I defend the actions of Qantas whenever possible

I encourage friends and relatives to fly with Qantas

Perceptions of organizational culture

being people oriented

being fair

being supportive

respecting individual rights

desiring to be a good corporate citizen

caring about the community it serves

focusing and solving customer problems

caring more about financial results than service delivery

feeling oppressed/ constrained by environmental forces in the global aviation market

Perceptions of internal resources

Has the financial capacity to run a great airline

Has the resources to help reduce environmental pollution (e.g. invest in fuel-efficient aircrafts)

Is strong enough to make a positive contribution to the local economy

Has a brand that people respect

Has support from the local community

Has a CEO known for his support of corporate social responsible

initiatives

Employees take pride in what they do

Employees are committed to their work

Perceptions of external environment

The airline industry is struggling to survive

High fuel costs globally present a problem for Qantas

High Australian dollars is a disadvantage to Qantas

$\begin{array}{crrr}\text { F1 } & \text { F2 } & \text { F3 } & \text { F4 } \\ 0.700 & 0.132 & -0.365 & 0.114 \\ 0.627 & 0.074 & -0.222 & 0.290 \\ 0.609 & 0.062 & -0.246 & 0.198 \\ 0.871 & -0.226 & 0.352 & 0.287 \\ 0.150 & 0.618 & -0.020 & -0.202 \\ 0.090 & 0.802 & 0.089 & -0.081 \\ 0.020 & 0.683 & 0.080 & -0.210 \\ 0.119 & 0.799 & 0.102 & -0.033 \\ 0.120 & -0.387 & 0.811 & -0.021 \\ 0.118 & -0.294 & 0.837 & -0.048 \\ 0.031 & -0.159 & 0.847 & -0.019 \\ 0.067 & -0.271 & 0.850 & -0.004 \\ 0.162 & 0.247 & 0.349 & 0.623 \\ 0.162 & 0.155 & 0.235 & 0.617 \\ 0.165 & 0.144 & -0.088 & 0.653 \\ 0.167 & 0.150 & 0.230 & 0.670 \\ \mathrm{~F} 1 & & & \end{array}$

F1

0.931

0.934

0.916

0.949

F1

0.880

0.933

0.854

0.940

F1

$0.884 \quad 0.067$

$0.927 \quad 0.066$

$0.934 \quad 0.069$

$0.925 \quad 0.012$

$0.864 \quad 0.003$

$0.869 \quad 0.044$

$0.119 \quad 0.846$

$-0.035 \quad 0.855$

$0.134 \quad 0.823$

F1 F2

$0.881 \quad 0.188$

$0.892 \quad 0.130$

$0.890 \quad 0.218$

$0.610 \quad 0.227$

$0.675 \quad 0.142$

$0.011 \quad 0.635$

$0.174 \quad 0.870$

$0.203 \quad 0.831$

F1

0.618

0.773

0.673

Table AII.

Factor loadings 
Qantas faces a hostile union locally

Competition from other airlines is affecting Qantas' business

0.715

Qantas faces very strong government regulations locally

The general public is increasingly dissatisfied with Qantas

The media is critical of Qantas

Personal values

Support charities and social services projects

Ensure that products and operations do not harm the environment

Treat all employees equally regardless of gender, race religion or sexuality

Improve education and skills in communities where they operate

Not only protect the environment but also restore it for future generations

Ensure that all materials it uses to make its products have been produced in a responsible manner

Play a role in our society that goes beyond the mere generation of profits

Would expectations

Support works to help the disadvantaged in society

Undertake actions to defend (protect) the environment

Make donations to worthy causes of social justices such as education

Support organizations that defend culture and sports

Support adequate employee welfare such as better working conditions

Care about more than its profit and financial performance

Could expectations

Support works to help the disadvantaged in society

Undertake actions to defend (protect) the environment

Make donations to worthy causes of social justices such as education

Support organizations that defend culture and sports

Support adequate employee welfare such as better working conditions

Care about more than its profit and financial performance

Should expectations

Support works to help the disadvantaged in society

Undertake actions to defend (protect) the environment

Make donations to worthy causes of social justices such as education

Support organizations that defend culture and sports

Support adequate employee welfare such as better working conditions

Care about more than its profit and financial performance

Attitude toward news

I regard this as good news

I am pleasantly surprised by this news

I would describe this news as positive

I am overall pleased with what I have read

Beliefs about the firm fit $_{t+1}$

Qantas is constantly improving

Qantas has a stable business

Qantas is a trouble-free airline

Qantas is not as good as it was three years ago

Qantas flights run on-time

When I have a problem, Qantas is sympathetic and reassuring

Qantas promptly informs me of my booked flight delays

Employees of Qantas are always willing to help me with my needs

Qantas employees care how I feel

Employees of Qantas know what my needs are

Qantas has my best interest at heart

Qantas gives me attention

Supports local communities
0.620

$\mathrm{F} 1$

0.740

0.859

0.805

0.815

0.890

0.898

0.871

F1

0.874

0.866

0.899

0.802

0.763

0.625

F1

0.873

0.843

0.882

0.842

0.730

0.614

$\mathrm{F} 1$

0.802

0.644

0.844

0.766

0.715

0.733

F1

0.960

0.920

0.968

0.972

\begin{tabular}{cccr} 
F1 & F2 & F3 & \multicolumn{1}{c}{ F4 } \\
0.283 & 0.236 & 0.656 & 0.329 \\
0.163 & 0.285 & 0.833 & 0.044 \\
0.192 & 0.195 & 0.845 & -0.026 \\
0.007 & 0.009 & 0.997 & 0.006 \\
0.590 & 0.174 & 0.313 & 0.007 \\
0.785 & 0.271 & 0.354 & 0.011 \\
0.712 & 0.249 & 0.261 & -0.037 \\
0.846 & 0.231 & 0.273 & 0.066 \\
0.252 & 0.002 & 0.310 & 0.800 \\
0.250 & 0.010 & 0.268 & 0.830 \\
0.409 & -0.021 & 0.179 & 0.682 \\
0.335 & -0.021 & 0.366 & 0.761 \\
0.181 & 0.881 & 0.245 & 0.044
\end{tabular}

\section{Role of expectations on consumer interpretation}

605 
Contributes to environment pollution reduction

Cares about its employees' welfare

Encourages corporate giving to worthy causes

Attitude toward the firm trt $_{t+1}$

I think Qantas is a great airline

I admire Qantas

I trust Qantas

I like Qantas very much

Behavioral intention toward the firm tri $_{t+1}$

I choose Qantas as my first choice whenever possible

I speak highly of Qantas to other people

I defend the actions of Qantas whenever possible

I encourage friends and relatives to fly with Qantas $\begin{array}{llll}0.179 & 0.857 & 0.270 & 0.038\end{array}$

$\begin{array}{llll}0.222 & 0.704 & 0.227 & -0.087\end{array}$

$\begin{array}{llll}0.191 & 0.879 & 0.254 & -0.003\end{array}$

F1

0.946

0.943

0.922

0.961

F1

0.906

0.957

0.885

0.960

Table AII.

Notes: Numbers represent loadings of items onto each of the factors. EFA conducted in pilot study 


\section{Appendix 7}
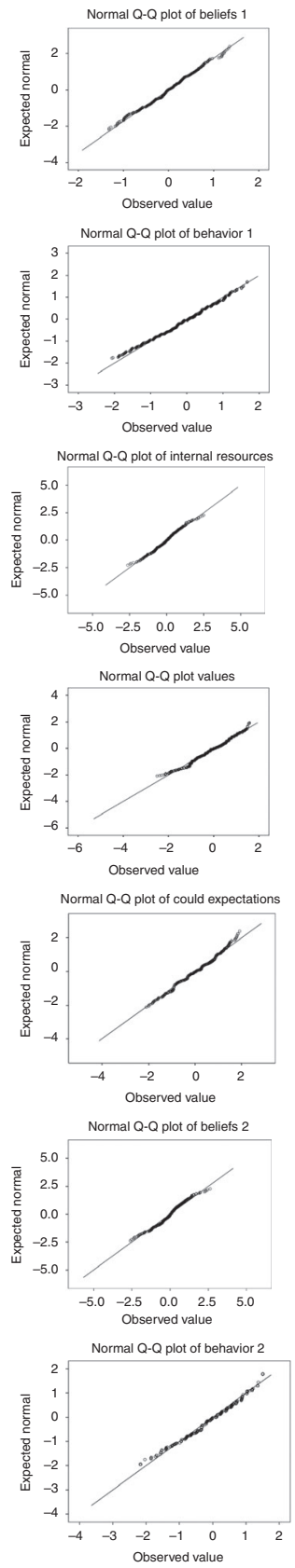

Role of expectations on consumer interpretation
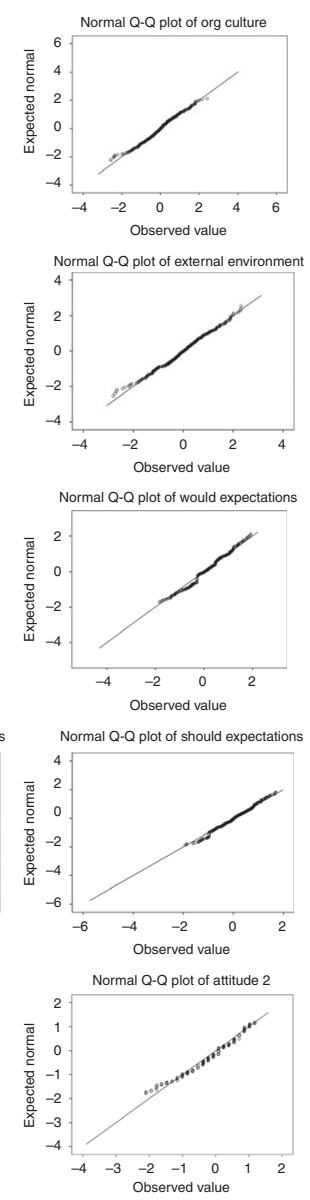

Figure A1.

Distribution data of data 
JSTP

27,3

608

Table AIII.

Moments of items (means, standard deviation, kurtosis and skewness)

\section{Appendix 8}

Airline passengers

Items

Mean SD Skewness Kurtosis

Beliefs about firm $t_{t}$

Qantas is constantly improving

Qantas has a stable business

Qantas is a trouble-free airline

Qantas is not as good as it was three years ago

Qantas flights run on-time

When I have a problem, Qantas is sympathetic and reassuring

Qantas promptly informs me of my booked flight delays

Employees of Qantas are always willing to help me with my needs

Qantas employees care how I feel

Employees of Qantas understand my needs

Qantas has my best interest at heart

Qantas gives me attention

Supports local communities

Contributes to environment pollution reduction

Cares about its employees' welfare

Encourages corporate giving to worthy causes

Attitude toward firm f $_{t}$

I think Qantas is a great airline

I admire Qantas

I trust Qantas

I like Qantas very much

Behavior toward firm

I recommend Qantas to friends and relatives whenever possible

I speak highly of Qantas to other people

I defend the actions of Qantas whenever possible

I encourage my friends and relatives to fly with Qantas

Perception of organizational culture

Being people oriented

Being fair

Being supportive

Respecting individual rights

Desiring to be a good corporate citizen

Caring about the community it serves

Focusing and solving customer problems

Caring more about financial results than service delivery

Feeling oppressed/ constrained by environmental forces in the global aviation market

\section{Perception of internal resources}

Has the financial capacity to run a great airline

Has the resources to help reduce environmental pollution (e.g. invest in fuel-efficient aircrafts)

Is strong enough to make a positive contribution to the local economy

Has a brand that people respect

Has support from the local community

Has a CEO known for his support of corporate social responsible initiatives

Employees take pride in what they do

Employees are committed to their work

$\begin{array}{rrrr}4.07 & 1.42 & -0.135 & -0.002 \\ 4.55 & 1.49 & -0.488 & -0.361 \\ 3.66 & 1.60 & 0.144 & -0.777 \\ 3.40 & 1.52 & -0.252 & -0.547 \\ 4.97 & 1.38 & -0.768 & 0.124 \\ 4.36 & 1.40 & -0.453 & 0.174 \\ 4.54 & 1.42 & -0.313 & -0.072 \\ 4.82 & 1.47 & -0.751 & 0.190 \\ 4.41 & 1.47 & -0.414 & -0.215 \\ 4.41 & 1.44 & -0.460 & 0.031 \\ 4.16 & 1.50 & -0.231 & -0.335 \\ 4.35 & 1.50 & -0.379 & -0.189 \\ 4.53 & 1.27 & -0.109 & 0.174 \\ 4.37 & 1.24 & -0.181 & 0.454 \\ 3.73 & 1.45 & -0.027 & -0.291 \\ 4.30 & 1.18 & -0.168 & 0.702\end{array}$

$\begin{array}{llll}4.98 & 1.42 & -0.502 & 0.048\end{array}$

$\begin{array}{llll}4.63 & 1.54 & -0.345 & -0.374\end{array}$

$\begin{array}{llll}4.83 & 1.50 & 0.003 & -0.259\end{array}$

$\begin{array}{llll}4.81 & 1.47 & -0.286 & -0.255\end{array}$

$\begin{array}{llll}4.79 & 1.50 & -0.502 & -0.886\end{array}$

$\begin{array}{llll}4.52 & 1.56 & -0.345 & -0.584\end{array}$

$\begin{array}{llll}3.77 & 1.49 & 0.003 & -0.643\end{array}$

$\begin{array}{llll}4.28 & 1.68 & -0.286 & -0.522\end{array}$

$\begin{array}{llll}4.24 & 1.48 & -0.347 & -0.214\end{array}$

$\begin{array}{llll}4.24 & 1.45 & -0.376 & -0.208\end{array}$

$\begin{array}{llll}4.25 & 1.43 & -0.357 & -0.066\end{array}$

$\begin{array}{llll}4.23 & 1.45 & -0.337 & -0.124\end{array}$

$\begin{array}{llll}4.50 & 1.44 & -0.530 & 0.227\end{array}$

$\begin{array}{llll}4.38 & 1.41 & -0.423 & 0.110\end{array}$

$\begin{array}{llll}4.42 & 1.43 & -0.537 & 0.066\end{array}$

$\begin{array}{llll}4.89 & 1.47 & -0.372 & -0.390\end{array}$

$\begin{array}{llll}4.60 & 1.21 & -0.064 & 0.688\end{array}$

$\begin{array}{llll}5.31 & 1.24 & -0.907 & 1.069\end{array}$

$\begin{array}{llll}5.20 & 1.13 & -0.581 & 0.595\end{array}$

$\begin{array}{llll}5.39 & 1.11 & -0.767 & 1.094\end{array}$

$\begin{array}{llll}5.22 & 1.37 & -0.813 & 0.425\end{array}$

$\begin{array}{rrrr}4.76 & 1.21 & -0.481 & 0.507\end{array}$

$\begin{array}{llll}3.66 & 1.61 & -0.072 & -0.407\end{array}$

$\begin{array}{llll}4.66 & 1.42 & -0.507 & 0.241\end{array}$

$\begin{array}{llll}4.72 & 1.41 & -0.546 & 0.199\end{array}$ 
Airline passengers

Items
Mean SD Skewness Kurtosis

Perception of external environment

The airline industry is struggling to survive

High fuel costs globally present a problem for Qantas

High Australian dollars is a disadvantage to Qantas

Qantas faces a hostile union locally

Competition from other airlines is affecting Qantas' business

Qantas faces very strong government regulations locally

The general public is increasingly dissatisfied with Qantas

The media is critical of Qantas

Personal values

Ensure that products and operations do not harm the environment

Treat all employees equally regardless of gender, race religion or sexuality

Improve education and skills in communities where they operate

Not only protect the environment but also restore it for future generations

Ensure that all materials it uses to make its products have been produced

in a responsible manner

Play a role in our society that goes beyond the mere generation of profits

\section{Should expectations}

Support works to help the disadvantaged in society

Undertake actions to defend (protect) the environment

Make donations to worthy causes of social justices such as education

Support organizations that defend culture and sports

Support adequate employee welfare such as better working conditions

Care about more than its profit and financial performance

\section{Would expectations}

Support works to help the disadvantaged in society

Undertake actions to defend (protect) the environment

Make donations to worthy causes of social justices such as education

Support organizations that defend culture and sports

Support adequate employee welfare such as better working conditions

Care about more than its profit and financial performance

\section{Could expectations}

Support works to help the disadvantaged in society

Undertake actions to defend (protect) the environment

Make donations to worthy causes of social justices such as education

Support organizations that defend culture and sports

Support adequate employee welfare such as better working conditions

Care about more than its profit and financial performance

\section{Positive news}

Attitude toward news t $_{t}$

I regard this as good news

I am pleasantly surprised by this news

I would describe this news as positive

I am overall pleased with what I have read

Beliefs about firm t+1 $_{1}$

Qantas is constantly improving

Qantas has a stable business

Qantas is a trouble-free airline

Qantas is not as good as it was three years ago

Qantas flights run on-time

$\begin{array}{rrrr}4.53 & 1.58 & -0.370 & -0.503 \\ 5.40 & 1.22 & -0.776 & 0.654 \\ 4.71 & 1.48 & -0.245 & -0.214 \\ 4.92 & 1.50 & -0.290 & -0.253 \\ 5.30 & 1.31 & -0.718 & 0.403 \\ 4.64 & 1.21 & -0.034 & 0.352 \\ 4.69 & 1.50 & 0.209 & -0.419 \\ 5.15 & 1.32 & -0.454 & 0.222 \\ & & & \\ 5.51 & 1.20 & -0.712 & 1.032 \\ 6.01 & 1.27 & -1.265 & 1.457 \\ 4.91 & 1.42 & -0.413 & 0.154 \\ 5.12 & 1.30 & -0.531 & 0.495 \\ & & & \\ 5.46 & 1.26 & -0.705 & 0.859 \\ 5.35 & 1.40 & -0.842 & 1.015\end{array}$

$\begin{array}{llll}4.38 & 1.33 & -0.342 & 0.655\end{array}$

$\begin{array}{llll}5.14 & 1.22 & -0.644 & 1.602\end{array}$

$\begin{array}{llll}4.47 & 1.31 & -0.442 & 0.751\end{array}$

$\begin{array}{llll}4.34 & 1.25 & -0.411 & 0.883\end{array}$

$\begin{array}{llll}5.51 & 1.17 & -0.984 & 1.824\end{array}$

$\begin{array}{llll}5.18 & 1.49 & -0.686 & 0.167\end{array}$

$\begin{array}{llll}4.57 & 1.37 & -0.541 & 0.928\end{array}$

$\begin{array}{llll}5.13 & 1.25 & -0.818 & 1.895\end{array}$

$\begin{array}{llll}4.62 & 1.34 & -0.547 & 0.967\end{array}$

$\begin{array}{llll}4.54 & 1.36 & -0.522 & 1.244\end{array}$

$\begin{array}{llll}5.57 & 1.19 & -1.093 & 2.649\end{array}$

$\begin{array}{llll}5.33 & 1.42 & -0.801 & 0.850\end{array}$

$\begin{array}{llll}4.21 & 1.31 & -0.559 & 1.180\end{array}$

$\begin{array}{llll}4.56 & 1.24 & -0.673 & 1.644\end{array}$

$\begin{array}{llll}4.92 & 1.34 & -0.547 & 0.967\end{array}$

$\begin{array}{llll}4.74 & 1.36 & -0.522 & 1.244\end{array}$

$\begin{array}{lllr}4.72 & 1.43 & -0.620 & 0.769\end{array}$

$\begin{array}{llll}4.48 & 1.61 & -0.404 & -0.075\end{array}$

$\begin{array}{llll}5.22 & 1.49 & -1.196 & 2.529 \\ 5.05 & 1.51 & -0.974 & 1.830 \\ 5.38 & 1.47 & -1.488 & 3.453 \\ 5.30 & 1.48 & -1.336 & 2.975 \\ & & & \\ 5.22 & 1.49 & -1.336 & 1.650 \\ 5.05 & 1.51 & -1.005 & 1.071 \\ 5.38 & 1.47 & -1.159 & 1.218 \\ 5.30 & 1.48 & -0.287 & 0.683 \\ 4.74 & 1.50 & -0.244 & 1.337\end{array}$

Role of expectations on consumer interpretation

609 
Airline passengers

When I have a problem, Qantas is sympathetic and reassuring Mean SD Skewness Kurtosis

Qantas promptly informs my customers of their booked flight delays

$\begin{array}{lll}4.84 & 1.42 & -0.923\end{array}$

2.497

Employees of Qantas are always willing to help me with my needs

$\begin{array}{lll}3.87 & 1.52 & -0.843\end{array}$

2.774

Qantas employees care how I feel

Employees of Qantas understand my customers' needs

Qantas has my customers' best interest at heart

Qantas gives me attention

Supports local communities

Contributes to environment pollution reduction

Cares about its employees' welfare

$\begin{array}{lll}4.22 & 1.58 & -0.737\end{array}$

0.308

$\begin{array}{llll}4.58 & 1.49 & -1.026 & 2.178\end{array}$

$\begin{array}{llll}4.51 & 1.47 & -0.820 & 1.650\end{array}$

$\begin{array}{llll}4.62 & 1.44 & -0.839 & 1.071\end{array}$

$\begin{array}{llll}4.78 & 1.53 & -0.749 & 1.218\end{array}$

$\begin{array}{llll}4.53 & 1.55 & -0.875 & 0.683\end{array}$

$\begin{array}{llll}4.51 & 1.52 & -1.040 & 1.337\end{array}$

Encourages corporate giving to worthy causes

$\begin{array}{lll}4.43 & 1.58 & -1.169\end{array}$

1.337
2.497

$\begin{array}{llll}4.55 & 1.52 & -0.725 & 2.774\end{array}$

Attitude toward firm $_{t+1}$

I think Qantas is a great airline

I admire Qantas

I trust Qantas

I like Qantas very much

$\begin{array}{llll}5.02 & 1.69 & -1.045 & 1.064\end{array}$

$\begin{array}{llll}4.71 & 1.63 & -0.747 & 0.739\end{array}$

$\begin{array}{llll}4.93 & 1.50 & 0.003 & -0.259\end{array}$

Behavior toward firm fit $_{t}$

I recommend Qantas to friends and relatives whenever possible

$\begin{array}{lll}4.90 & 1.69 & -0.909\end{array}$

0.784

I speak highly of Qantas to my friends and relatives

$\begin{array}{llll}4.84 & 1.96 & -1.045 & 1.064\end{array}$

I defend the actions of Qantas whenever possible

$\begin{array}{lll}4.62 & 1.70 & -0.747\end{array}$

0.739

I encourage my friends and relatives to fly with Qantas

$\begin{array}{lll}4.21 & 1.67 & -0.836\end{array}$

0.568

Table AIII. 


\begin{tabular}{|c|c|c|c|c|c|c|c|c|}
\hline Items & $\begin{array}{l}\text { Second } \\
\text { order } \\
\text { factor }\end{array}$ & Code & $\begin{array}{c}\text { Std } \\
\text { loadings }\end{array}$ & $\mathrm{SE}$ & $\begin{array}{l}\text { Construct } \\
\text { reliability }\end{array}$ & AVE & $\begin{array}{l}\text { CFI/ } \\
\text { TLI }\end{array}$ & RMSEA \\
\hline \multirow[t]{2}{*}{ Beliefs about firm $t$} & & & & & $0.917 *$ & $0.667^{*}$ & $\begin{array}{l}0.981 / \\
0.950 *\end{array}$ & $0.051^{*}$ \\
\hline & Reputation & $\mathrm{RP} 1$ & 0.942 & 0.031 & 0.792 & 0.731 & $\begin{array}{l}1.00 / \\
1.00\end{array}$ & 0.000 \\
\hline Qantas is constantly improving & Reputation & A1 & 0.849 & 0.011 & & & & \\
\hline Qantas has a stable business & Reputation & A2 & 0.893 & 0.01 & & & & \\
\hline Qantas is a trouble-free airline & Reputation & A3 & 0.833 & 0.012 & & & & \\
\hline \multirow{2}{*}{$\begin{array}{l}\text { Qantas is not as good as it was } \\
\text { three years ago }\end{array}$} & Reputation & A4 & 0.844 & 0.033 & & & & \\
\hline & Reliability & RL1 & 0.957 & 0.0 .34 & 0.830 & 0.605 & $\begin{array}{l}0.973 / \\
0.980\end{array}$ & 0.040 \\
\hline Qantas flights run on-time & Reliability & A5 & 0.778 & 0.033 & & & & \\
\hline $\begin{array}{l}\text { When I have a problem, Qantas is } \\
\text { sympathetic and reassuring }\end{array}$ & Reliability & A6 & 0.841 & 0.012 & & & & \\
\hline $\begin{array}{l}\text { Qantas promptly informs me of } \\
\text { my booked flight delays }\end{array}$ & Reliability & A7 & 0.867 & 0.001 & & & & \\
\hline \multirow{2}{*}{$\begin{array}{l}\text { Employees of Qantas are always } \\
\text { willing to help me with my needs }\end{array}$} & Reliability & A8 & 0.909 & 0.009 & & & & \\
\hline & Empathy & $\mathrm{EP} 1$ & 0.928 & 0.025 & 0.935 & 0.612 & $\begin{array}{l}0.981 / \\
0.933\end{array}$ & 0.050 \\
\hline Qantas employees care how I feel & Empathy & A9 & 0.778 & 0.016 & & & & \\
\hline $\begin{array}{l}\text { Employees of Qantas understand } \\
\text { my customers' needs }\end{array}$ & Empathy & $\mathrm{A} 10$ & 0.798 & 0.016 & & & & \\
\hline $\begin{array}{l}\text { Qantas has my best interest at } \\
\text { heart }\end{array}$ & Empathy & A11 & 0.735 & 0.025 & & & & \\
\hline \multirow[t]{2}{*}{ Qantas gives me attention } & Empathy & $\mathrm{A} 12$ & 0.765 & 0.019 & & & & \\
\hline & CSR & CS1 & 0.728 & 0.033 & 0.845 & 0.646 & $\begin{array}{l}0.951 / \\
0.945\end{array}$ & 0.050 \\
\hline $\begin{array}{l}\text { Qantas supports local } \\
\text { communities }\end{array}$ & CSR & $\mathrm{A} 13$ & 0.722 & 0.034 & & & & \\
\hline $\begin{array}{l}\text { Qantas contributes to } \\
\text { environment pollution reduction }\end{array}$ & CSR & A14 & 0.765 & 0.015 & & & & \\
\hline $\begin{array}{l}\text { Qantas cares about its } \\
\text { employees' welfare }\end{array}$ & CSR & A15 & 0.931 & 0.015 & & & & \\
\hline $\begin{array}{l}\text { Qantas encourages corporate } \\
\text { giving to worthy causes }\end{array}$ & CSR & A16 & 0.714 & 0.015 & & & & \\
\hline Attitude toward firm $t$ & & & & & $0.950^{*}$ & $0.614^{*}$ & $\begin{array}{l}0.993 / \\
0.978^{*}\end{array}$ & $0.050^{*}$ \\
\hline I think Qantas is a great airline & & B1 & 0.704 & 0.016 & & & & \\
\hline I admire Qantas & & B2 & 0.817 & 0.011 & & & & \\
\hline I trust Qantas & & B3 & 0.799 & 0.017 & & & & \\
\hline I like Qantas very much & & B4 & 0.809 & 0.019 & & & & \\
\hline Behavior toward firm $t$ & & & & & $0.924^{*}$ & $0.633^{*}$ & $\begin{array}{l}0.992 / \\
0.978^{*}\end{array}$ & $0.050^{*}$ \\
\hline $\begin{array}{l}\text { I recommend Qantas as my } \\
\text { clients whenever possible }\end{array}$ & & $\mathrm{C} 1$ & 0.867 & 0.031 & & & & \\
\hline I speak highly of Qantas to other & & $\mathrm{C} 2$ & 0.648 & 0.02 & & & & \\
\hline
\end{tabular}

Qantas is constantly improving Qantas has a stable business three years ago

Qantas flights run on-time Reliability sympathetic and reassuring Qantas promptly informs me of my booked flight delays

Employees of Qantas are always
willing to help me with my needs

Qantas employees care how I feel Empathy

Employees of Qantas understand Empathy my customers' needs

heart

Qantas gives me attention

Qantas supports local

Qantas contributes to

environment pollution reduction

Qantas cares about its

employees' welfare

Qantas encourages corporate

giving to worthy causes people (continued)
Table AIV. Measurement model (main study) 


\begin{tabular}{llllllllll}
\hline & $\begin{array}{l}\text { Second } \\
\text { order } \\
\text { factor }\end{array}$ & Code & \multicolumn{1}{c}{$\begin{array}{c}\text { Std } \\
\text { lteadings }\end{array}$} & SE & $\begin{array}{l}\text { Construct } \\
\text { reliability }\end{array}$ & AVE & TLI & RMSEA \\
\hline
\end{tabular}

I defend the actions of Qantas whenever possible

I encourage my friends and relatives to fly with Qantas Perceptions of organizational culture

Being people oriented

Being fair

Being supportive

Respecting individual rights

Desiring to be a good corporate citizen

Caring about the community it serves

Focusing and solving customer problems

Caring more about financial results than service delivery

Feeling oppressed/ constrained by environmental forces in the global aviation market

Perception of internal resources

Business

Business

$\begin{array}{lll}\text { C3 } & 0.857 & 0.012\end{array}$

$\begin{array}{lll}\text { C4 } & 0.792 & 0.014\end{array}$

$\begin{array}{lllllllll} & & & & 0.897^{*} & 0.726^{*} & 0.940 / & 0.050^{*} \\ \text { People } \quad \text { PPL } & 0.974 & 0.024 & 0.956 & 0.720 & 0.981 / & 0.060 \\ & & & & & & 0.948 & \end{array}$

$\begin{array}{llll}\text { People } & \text { O2 } & 0.885 & 0.008\end{array}$

$\begin{array}{llll}\text { People } & \text { O3 } & 0.885 & 0.008\end{array}$

$\begin{array}{llll}\text { People } & 04 & 0.869 & 0.009\end{array}$

$\begin{array}{llll}\text { People } & \text { O5 } & 0.906 & 0.007\end{array}$

$\begin{array}{llll}\text { People } & \text { O6 } & 0.654 & 0.023\end{array}$

Business

$\begin{array}{lll}\mathrm{BIZ} & 0.994 & 0.013\end{array}$

$\begin{array}{lll}07 & 0.869 & 0.011\end{array}$

0.767

$0.739 \quad 1.00 /$

.1 .00

0.001

$$
\begin{array}{lll}
08 & 0.822 & 0.013
\end{array}
$$

$\begin{array}{lll}09 & 0.886 & 0.01\end{array}$

Tangible

TAN

0.704

0.006

\begin{tabular}{|c|c|c|}
\hline $0.867 *$ & $0.814^{*}$ & $0.950 /$ \\
\hline & & $0.949 *$ \\
\hline 870 & 0.833 & $\begin{array}{c}0.984 / \\
0.941\end{array}$ \\
\hline
\end{tabular}

Has the financial capacity to run Tangible a great airline

Has the resources to help reduce Tangible

I1 $\quad 0.917 \quad 0.006$

environmental pollution (e.g. invest in fuel-efficient aircrafts)

Is strong enough to make a
positive contribution to the local Intangible

0.908

0.006

economy

Has a brand that people respect

Has support from the local community

Intangible

ITAN

I3

1.0

0.009

0.910

0.831

$0.990 / \quad 0.030$ 0.950

$\begin{array}{llll}\text { Intangible } & \text { I4 } & 0.944 & 0.004\end{array}$ $\begin{array}{llll}\text { Intangible } & \text { I5 } & 0.818 & 0.011\end{array}$

\section{Human}

Has a CEO known for his support Human of corporate social responsible initiatives

Employees take pride in what Human they do

Employees are committed to their Human work

$\begin{array}{ccc}\text { HUM } & 0.972 & 0.008 \\ \text { I6 } & 0.958 & 0.004 \\ & & \\ \text { I7 } & 0.842 & 0.005 \\ \text { I8 } & 0.939 & 0.007\end{array}$

Table AIV.

(continued) 


\begin{tabular}{|c|c|c|c|c|c|c|c|c|}
\hline Items & $\begin{array}{l}\text { Second } \\
\text { order } \\
\text { factor }\end{array}$ & Code & $\begin{array}{c}\text { Std } \\
\text { loadings }\end{array}$ & $\mathrm{SE}$ & $\begin{array}{l}\text { Construct } \\
\text { reliability }\end{array}$ & AVE & $\begin{array}{l}\mathrm{CFI} / \\
\mathrm{TLI}\end{array}$ & RMSEA \\
\hline $\begin{array}{l}\text { Perception of external } \\
\text { environment }\end{array}$ & & & & & $0.796^{*}$ & $0.614^{*}$ & $\begin{array}{l}0.951 / \\
0.946^{*}\end{array}$ & $0.048^{*}$ \\
\hline $\begin{array}{l}\text { The airline industry is struggling } \\
\text { to survive }\end{array}$ & & E1 & 0.869 & 0.025 & & & & \\
\hline $\begin{array}{l}\text { High fuel costs globally present a } \\
\text { problem for Qantas }\end{array}$ & & E2 & 0.756 & 0.015 & & & & \\
\hline $\begin{array}{l}\text { High Australian dollars is a } \\
\text { disadvantage to Qantas }\end{array}$ & & E3 & 0.763 & 0.019 & & & & \\
\hline $\begin{array}{l}\text { Qantas faces a hostile union } \\
\text { locally }\end{array}$ & & $\mathrm{E} 4$ & 0.846 & 0.020 & & & & \\
\hline $\begin{array}{l}\text { Competition from other airlines is } \\
\text { affecting Qantas' business }\end{array}$ & & E5 & 0.714 & 0.023 & & & & \\
\hline $\begin{array}{l}\text { Qantas faces very strong } \\
\text { government regulations locally }\end{array}$ & & E6 & 0.729 & 0.021 & & & & \\
\hline $\begin{array}{l}\text { The general public is increasingly } \\
\text { dissatisfied with Qantas }\end{array}$ & & E7 & 0.849 & 0.011 & & & & \\
\hline The media is critical of Qantas & & E8 & 0.726 & 0.016 & & & & \\
\hline Personal values & & & & & $0.935^{*}$ & $0.632 *$ & $\begin{array}{l}0.980 / \\
0.953^{*}\end{array}$ & $0.040^{*}$ \\
\hline $\begin{array}{l}\text { Support charities and social } \\
\text { services projects }\end{array}$ & & P1 & 0.882 & 0.013 & & & & \\
\hline $\begin{array}{l}\text { Ensure that products and } \\
\text { operations do not harm the } \\
\text { environment }\end{array}$ & & P2 & 0.762 & 0.015 & & & & \\
\hline $\begin{array}{l}\text { Treat all employees equally } \\
\text { regardless of gender, race } \\
\text { religion or sexuality }\end{array}$ & & P3 & 0.618 & 0.021 & & & & \\
\hline $\begin{array}{l}\text { Improve education and skills in } \\
\text { communities where they operate }\end{array}$ & & $\mathrm{P} 4$ & 0.745 & 0.027 & & & & \\
\hline $\begin{array}{l}\text { Not only protect the environment } \\
\text { but also restore it for future } \\
\text { generations }\end{array}$ & & P5 & 0.807 & 0.023 & & & & \\
\hline $\begin{array}{l}\text { Ensure that all materials it uses to } \\
\text { make its products have been } \\
\text { produced in a responsible manner }\end{array}$ & & P6 & 0.887 & 0.032 & & & & \\
\hline $\begin{array}{l}\text { Play a role in our society that } \\
\text { goes beyond the mere generation } \\
\text { of profits }\end{array}$ & & $\mathrm{P} 7$ & 0.833 & 0.031 & & & & \\
\hline Should expectations & & & & & $0.847^{*}$ & $0.616^{*}$ & $\begin{array}{l}0.993 / \\
0.783^{*}\end{array}$ & $0.051^{*}$ \\
\hline $\begin{array}{l}\text { Support works to help the } \\
\text { disadvantaged in society }\end{array}$ & & SE1 & 0.789 & 0.026 & & & & \\
\hline $\begin{array}{l}\text { Undertake actions to defend } \\
\text { (protect) the environment }\end{array}$ & & SE2 & 0.802 & 0.025 & & & & \\
\hline $\begin{array}{l}\text { Make donations to worthy causes } \\
\text { of social justices such as } \\
\text { education }\end{array}$ & & SE3 & 0.785 & 0.031 & & & & \\
\hline $\begin{array}{l}\text { Support organizations that } \\
\text { defend culture and sports }\end{array}$ & & SE4 & 0.682 & 0.011 & & & & \\
\hline $\begin{array}{l}\text { Support adequate employee } \\
\text { welfare such as better working }\end{array}$ & & SE5 & 0.847 & 0.013 & & & & \\
\hline
\end{tabular}

Role of expectations on consumer interpretation

problem for Qantas

High Australian dollars is a

locally

Competition from other airlines is

affecting Qantas' business

Qantas faces very strong

government regulations locally

dissatisfied with Qantas

The media is critical of Qantas

and socia

environment

religion or sexuality

Improve education and skills in

Second

order

Code loading

613

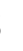




\begin{tabular}{|c|c|c|c|c|c|c|c|c|}
\hline Items & $\begin{array}{l}\text { Second } \\
\text { order } \\
\text { factor }\end{array}$ & Code & $\begin{array}{c}\text { Std } \\
\text { loadings }\end{array}$ & SE & $\begin{array}{l}\text { Construct } \\
\text { reliability }\end{array}$ & AVE & $\begin{array}{l}\text { CFI/ } \\
\text { TLI }\end{array}$ & RMSEA \\
\hline $\begin{array}{l}\text { Care about more than its profit } \\
\text { and financial performance }\end{array}$ & & SE6 & 0.795 & 0.014 & & & & \\
\hline Would expectations & & & & & $0.892 *$ & $0.643^{*}$ & $\begin{array}{l}0.960 / \\
0.950 *\end{array}$ & $0.041^{*}$ \\
\hline $\begin{array}{l}\text { Support works to help the } \\
\text { disadvantaged in society }\end{array}$ & & WE1 & 0.752 & 0.014 & & & & \\
\hline $\begin{array}{l}\text { Undertake actions to defend } \\
\text { (protect) the environment }\end{array}$ & & WE2 & 0.844 & 0.011 & & & & \\
\hline $\begin{array}{l}\text { Make donations to worthy causes } \\
\text { of social justices such as } \\
\text { education }\end{array}$ & & WE3 & 0.837 & 0.011 & & & & \\
\hline $\begin{array}{l}\text { Support organizations that } \\
\text { defend culture and sports }\end{array}$ & & WE4 & 0.799 & 0.012 & & & & \\
\hline $\begin{array}{l}\text { Support adequate employee } \\
\text { welfare such as better working } \\
\text { conditions }\end{array}$ & & WE5 & 0.763 & 0.024 & & & & \\
\hline Care about more than its profit & & WE6 & 0.812 & 0.019 & & & & \\
\hline
\end{tabular}

and financial performance

Could expectations

Support works to help the disadvantaged in society Undertake actions to defend (protect) the environment Make donations to worthy causes of social justices such as education Support organizations that defend culture and sports Support adequate employee welfare such as better working conditions

Care about more than its profit and financial performance

Positive news

Attitude toward news ${ }_{t}$

I regard this as good news I am pleasantly surprised by this news

I would describe this news as positive

I am overall pleased with what

I have read

Beliefs about firm ${ }_{t+1}$

$\begin{array}{lll}\text { AT1 } & 0.861 & 0.009\end{array}$

$\begin{array}{llll}0.968 * & 0.841 * & 0.999 / & 0.001 *\end{array}$

AT2 $0.946 \quad 0.004$

$\begin{array}{llll}0.886^{*} & 0.610^{*} & 0.953 / & 0.050^{*} \\ & & 0.941 * & \end{array}$

$\begin{array}{lll}\text { CE1 } & 0.848 & 0.013\end{array}$

$\begin{array}{lll}\text { CE2 } & 0.786 & 0.015\end{array}$

$\begin{array}{lll}\text { CE3 } & 0.782 & 0.027\end{array}$

$\begin{array}{lll}\text { CE4 } & 0.659 & 0.031\end{array}$

$\begin{array}{lll}\text { CE5 } & 0.813 & 0.014\end{array}$

$\begin{array}{lll}\text { CE6 } & 0.784 & 0.021\end{array}$

AT3 $\quad 0.956 \quad 0.004$

$\begin{array}{lll}\text { AT4 } & 0.902 & 0.007\end{array}$

Qantas is constantly improving Qantas has a stable business Qantas is a trouble-free airline Qantas is not as good as it was three years ago

$\begin{array}{llll} & \text { AT3 } & 0.956 & 0.004 \\ & \text { AT4 } & 0.902 & 0.007 \\ & & & \\ & & & \\ \text { Reputation } & \text { RP2 } & 0.780 & 0.029 \\ & & & \\ \text { Reputation } & \text { X1 } & 0.763 & 0.017 \\ \begin{array}{l}\text { Reputation } \\ \text { Reputation }\end{array} & \text { X3 } & 0.726 & 0.019 \\ \text { Reputation } & \text { X4 } & 0.766 & 0.021 \\ & & 0.884 & 0.031\end{array}$

Table AIV.

(continued) 


\begin{tabular}{|c|c|c|c|c|c|c|c|c|c|}
\hline Items & $\begin{array}{l}\text { Second } \\
\text { order } \\
\text { factor }\end{array}$ & Code & $\begin{array}{c}\text { Std } \\
\text { loadings }\end{array}$ & $\mathrm{SE}$ & $\begin{array}{l}\text { Construct } \\
\text { reliability }\end{array}$ & AVE & $\begin{array}{l}\text { CFI/ } \\
\text { TLI }\end{array}$ & RMSEA & $\begin{array}{l}\text { Role of } \\
\text { expectations } \\
\text { on consumer }\end{array}$ \\
\hline & Reliability & RL2 & 0.957 & 0.021 & 0.890 & 0.612 & $\begin{array}{l}0.993 / \\
0.993\end{array}$ & 0.040 & interpre \\
\hline Qantas flights run on-time & Reliability & $\mathrm{X} 5$ & 0.771 & 0.022 & & & & & \\
\hline $\begin{array}{l}\text { When I have a problem, Qantas is } \\
\text { sympathetic and reassuring }\end{array}$ & Reliability & $\mathrm{X} 6$ & 0.811 & 0.013 & & & & & 615 \\
\hline $\begin{array}{l}\text { Qantas promptly informs me of } \\
\text { my booked flight delays }\end{array}$ & Reliability & $\mathrm{X} 7$ & 0.759 & 0.019 & & & & & \\
\hline \multirow{2}{*}{$\begin{array}{l}\text { Employees of Qantas are always } \\
\text { willing to help me with my needs }\end{array}$} & Reliability & $\mathrm{X} 8$ & 0.786 & 0.014 & & & & & \\
\hline & Empathy & EP2 & 0.928 & 0.010 & 0.942 & 0.740 & $\begin{array}{l}0.955 / \\
0.945\end{array}$ & 0.050 & \\
\hline Qantas employees care how I feel & Empathy & X9 & 0.848 & 0.008 & & & & & \\
\hline $\begin{array}{l}\text { Employees of Qantas understand } \\
\text { my needs }\end{array}$ & Empathy & $\mathrm{X} 10$ & 0.864 & 0.009 & & & & & \\
\hline $\begin{array}{l}\text { Qantas has my best interest } \\
\text { at heart }\end{array}$ & Empathy & $\mathrm{X} 11$ & 0.852 & 0.011 & & & & & \\
\hline \multirow[t]{2}{*}{ Qantas gives me attention } & Empathy & $\mathrm{X} 12$ & 0.876 & 0.009 & & & & & \\
\hline & CSR & CS2 & 0.728 & 0.019 & 0.924 & 0.649 & $\begin{array}{c}0.961 / \\
0.922\end{array}$ & 0.051 & \\
\hline Supports local communities & CSR & $\mathrm{X} 13$ & 0.762 & 0.017 & & & & & \\
\hline $\begin{array}{l}\text { Contributes to environment } \\
\text { pollution reduction }\end{array}$ & CSR & $\mathrm{X} 14$ & 0.747 & 0.016 & & & & & \\
\hline Cares about its employees' welfare & CSR & $\mathrm{X} 15$ & 0.889 & 0.018 & & & & & \\
\hline $\begin{array}{l}\text { Encourages corporate giving to } \\
\text { worthy causes }\end{array}$ & CSR & $\mathrm{X} 16$ & 0.816 & 0.014 & & & & & \\
\hline Attitude toward firm $t_{t+1}$ & & & & & $0.958^{*}$ & $0.887^{*}$ & $\begin{array}{l}0.993 / \\
0.978^{*}\end{array}$ & $0.050^{*}$ & \\
\hline I think Qantas is a great airline & & Y1 & 0.893 & 0.007 & & & & & \\
\hline I admire Qantas & & $\mathrm{Y} 2$ & 0.882 & 0.008 & & & & & \\
\hline I trust Qantas & & Y3 & 0.855 & 0.009 & & & & & \\
\hline I like Qantas very much & & Y4 & 0.919 & 0.006 & & & & & \\
\hline Behavior toward firm $t_{t+1}$ & & & & & $0.946^{*}$ & $0.723^{*}$ & $\begin{array}{l}0.993 / \\
0.978^{*}\end{array}$ & $0.050^{*}$ & \\
\hline $\begin{array}{l}\text { I recommend Qantas as my } \\
\text { friends and relatives whenever } \\
\text { possible }\end{array}$ & & $\mathrm{Z1}$ & 0.813 & 0.011 & & & & & \\
\hline $\begin{array}{l}\text { I speak highly of Qantas to other } \\
\text { people }\end{array}$ & & $\mathrm{Z} 2$ & 0.928 & 0.006 & & & & & \\
\hline $\begin{array}{l}\text { I defend the actions of Qantas } \\
\text { whenever possible }\end{array}$ & & Z3 & 0.869 & 0.014 & & & & & \\
\hline $\begin{array}{l}\text { I encourage my friends and } \\
\text { relatives to fly with Qantas }\end{array}$ & & $\mathrm{Z4}$ & 0.891 & 0.008 & & & & & \\
\hline \multicolumn{9}{|c|}{ Notes: Construct reliabilities, AVE, CFI/TLI and RMSEA (italic) $=$ second factor order. *Significance at $p<0.05$} & Table AIV. \\
\hline
\end{tabular}

\section{Corresponding author}

John Heath Roberts can be contacted at: johnr@agsm.edu.au

For instructions on how to order reprints of this article, please visit our website: 
Reproduced with permission of the copyright owner. Further reproduction prohibited without permission. 